\title{
Programmed cell death in diazotrophs and the fate of organic matter in the western tropical South Pacific Ocean during the OUTPACE cruise
}

\author{
Dina Spungin ${ }^{1}$, Natalia Belkin ${ }^{1}$, Rachel A. Foster ${ }^{2}$, Marcus Stenegren $^{2}$, Andrea Caputo $^{2}$, Mireille Pujo-Pay $^{3}$, \\ Nathalie Leblond ${ }^{4}$, Cécile Dupouy ${ }^{4}$, Sophie Bonnet ${ }^{5}$, and Ilana Berman-Frank ${ }^{1, a}$ \\ ${ }^{1}$ The Mina and Everard Goodman Faculty of Life Sciences, Bar-Ilan University, Ramat-Gan, Israel \\ ${ }^{2}$ Stockholm University, Department of Ecology, Environment and Plant Sciences, Stockholm, Sweden \\ ${ }^{3}$ Laboratoire d'Océanographie Microbienne - UMR 7321, CNRS - Sorbonne Universités, UPMC Univ Paris 06, \\ Observatoire Océanologique, 66650 Banyuls-sur-Mer, France \\ ${ }^{4}$ Observatoire Océanologique de Villefranche, Laboratoire d'Océanographie de Villefranche, UMR 7093, \\ Villefranche-sur-Mer, France \\ ${ }^{5}$ Aix-Marseille Univ., Univ. Toulon, CNRS/INSU, IRD, UM 110, Mediterranean Institute of Oceanography (MIO) UM 110, \\ 13288, Centre IRD de Noumea, New Caledonia \\ ${ }^{a}$ current address: Leon H. Charney School of Marine Sciences, University of Haifa, Mt. Carmel, Haifa 3498838, Israel
}

Correspondence: Ilana Berman-Frank (iberman2@univ.haifa.ac.il)

Received: 4 January 2018 - Discussion started: 11 January 2018

Revised: 1 May 2018 - Accepted: 7 May 2018 - Published: 28 June 2018

\begin{abstract}
The fate of diazotroph ( $\mathrm{N}_{2}$ fixers) derived carbon $(\mathrm{C})$ and nitrogen $(\mathrm{N})$ and their contribution to vertical export of $\mathrm{C}$ and $\mathrm{N}$ in the western tropical South Pacific Ocean was studied during OUTPACE (Oligotrophy to UlTraoligotrophy PACific Experiment). Our specific objective during OUTPACE was to determine whether autocatalytic programmed cell death (PCD), occurring in some diazotrophs, is an important mechanism affecting diazotroph mortality and a factor regulating the vertical flux of organic matter and, thus, the fate of the blooms. We sampled at three long duration (LD) stations of 5 days each (LDA, LDB and LDC) where drifting sediment traps were deployed at 150, 325 and $500 \mathrm{~m}$ depth. LDA and LDB were characterized by high chlorophyll $a(\mathrm{Chl} a)$ concentrations $\left(0.2-0.6 \mu \mathrm{g} \mathrm{L}^{-1}\right)$ and dominated by dense biomass of the filamentous cyanobacterium Trichodesmium as well as UCYN-B and diatomdiazotroph associations (Rhizosolenia with Richelia-detected by microscopy and het-1 nifH copies). Station LDC was located at an ultra-oligotrophic area of the South Pacific gyre with extremely low Chl $a$ concentration $\left(\sim 0.02 \mu \mathrm{g} \mathrm{L}{ }^{-1}\right)$ with limited biomass of diazotrophs predominantly the unicellular UCYN-B. Our measurements of biomass from LDA and LDB yielded high activities of caspase-like and metacas-
\end{abstract}

pase proteases that are indicative of PCD in Trichodesmium and other phytoplankton. Metacaspase activity, reported here for the first time from oceanic populations, was highest at the surface of both LDA and LDB, where we also obtained high concentrations of transparent exopolymeric particles (TEP). TEP were negatively correlated with dissolved inorganic phosphorus and positively coupled to both the dissolved and particulate organic carbon pools. Our results reflect the increase in TEP production under nutrient stress and its role as a source of sticky carbon facilitating aggregation and rapid vertical sinking. Evidence for bloom decline was observed at both LDA and LDB. However, the physiological status and rates of decline of the blooms differed between the stations, influencing the amount of accumulated diazotrophic organic matter and mass flux observed in the traps during our experimental time frame. At LDA sediment traps contained the greatest export of particulate matter and significant numbers of both intact and decaying Trichodesmium, UCYN-B and het-1 compared to LDB where the bloom decline began only 2 days prior to leaving the station and to LDC where no evidence for bloom or bloom decline was seen. Substantiating previous findings from laboratory cultures linking PCD to carbon export in Trichodesmium, our results from OUT- 
PACE indicate that nutrient limitation may induce PCD in high biomass blooms such as displayed by Trichodesmium or diatom-diazotroph associations. Furthermore, PCD combined with high TEP production will tend to facilitate cellular aggregation and bloom termination and will expedite vertical flux to depth.

\section{Introduction}

The efficiency of the biological pump, essential in the transfer and sequestration of carbon to the deep ocean, depends on the balance between growth (production) and death. Moreover, the manner in which marine organisms die may ultimately determine the flow of fixed organic matter within the aquatic environment and whether organic matter is incorporated into higher trophic levels, is recycled within the microbial loop or sinks out (and is exported) to depth.

$\mathrm{N}_{2}$ fixing (diazotrophic) prokaryotic organisms are important contributors to the biological pump and their ability to fix atmospheric $\mathrm{N}_{2}$ confers an inherent advantage in the nitrogen-limited surface waters of many oceanic regions. The oligotrophic waters of the western tropical South Pacific (WTSP) Ocean have been characterized with some of the highest recorded rates of $\mathrm{N}_{2}$ fixation (151$700 \mu \mathrm{mol} \mathrm{N} \mathrm{m} \mathrm{d}^{-2} \mathrm{~d}^{-1}$ (Garcia et al., 2007; Bonnet et al., 2005) and can reach up to $1200 \mu \mathrm{mol} \mathrm{N} \mathrm{m} \mathrm{m}^{-2} \mathrm{~d}^{-1}$ (Bonnet et al., 2017). Diazotrophic communities comprised of unicellular cyanobacteria lineages (UCYN-A, B and C), diatomdiazotroph associations (DDA) such as Richelia associated with Rhizosolenia and diverse heterotrophic bacteria such as alpha and $\gamma$-proteobacteria are responsible for these rates of $\mathrm{N}_{2}$ fixation. The most conspicuous of all diazotrophs, and predominating in terms of biomass, is the filamentous bloomforming cyanobacterium Trichodesmium forming massive surface blooms that supply $\sim 60-80 \mathrm{Tg} \mathrm{N} \mathrm{yr}^{-1}$ of the 100 $200 \mathrm{Tg} \mathrm{N} \mathrm{yr}^{-1}$ of the estimated marine $\mathrm{N}_{2}$ fixation (Capone et al., 1997; Carpenter et al., 2004; Westberry and Siegel, 2006) with a large fraction fixed in the WTSP (Dupouy et al., 2000, 2011; Barboza Tenório et al., 2018) that may, based on NanoSIMS cell-specific measurements, contribute up to $\sim 80 \%$ of bulk $\mathrm{N}_{2}$ fixation rates in the WTSP (Bonnet et al., 2018).

How Trichodesmium blooms form and develop has been investigated intensely while little data are found regarding the fate of blooms. Trichodesmium blooms often collapse within 3-5 days, with mortality rates paralleling bloom development rates (Rodier and Le Borgne, 2008; Rodier and Le Borgne, 2010; Bergman et al., 2012). Cell mortality can occur due to grazing (O'Neil, 1998), viral lysis (Hewson et al., 2004; Ohki, 1999) and/or programmed cell death (PCD) an autocatalytic genetically controlled death (Berman-Frank et al., 2004). PCD is induced in response to oxidative and nutrient stress, as has been documented in both laboratory and natural populations of Trichodesmium (Berman-Frank et al., 2004; Berman-Frank et al., 2007) and in other phytoplankton (Bidle, 2015). The cellular and morphological features of PCD in Trichodesmium include elevated gene expression and activity of metacaspases and caspase-like proteins; hallmark protein families involved in PCD pathways in other organisms whose functions in Trichodesmium are currently unknown. PCD in Trichodesmium also displays increased production of transparent exopolymeric particles (TEP) and trichome aggregation as well as buoyancy loss via reduction in gas vesicles. This causes rapid sinking rates that can be significant when large biomass found in oceanic blooms crashes (Bar-Zeev et al., 2013; Berman-Frank et al., 2004).

Simulating PCD in laboratory cultures of Trichodesmium in $2 \mathrm{~m}$ water columns (Bar-Zeev et al., 2013) led to a collapse of the Trichodesmium biomass and to greatly enhanced sinking of large aggregates, reaching rates of up to $\sim 200 \mathrm{~m} \mathrm{~d}^{-1}$, that efficiently exported particulate organic carbon (POC) and particulate organic nitrogen (PON) to the bottom of the water column. Although the sinking rates and degree of export from this model system could not be extrapolated to the ocean, this study mechanistically linked autocatalytic PCD and bloom collapse to quantitative $\mathrm{C}$ and $\mathrm{N}$ export fluxes, suggesting that PCD may have an impact on the biological pump efficiency in the oceans (Bar-Zeev et al., 2013).

We further examined this issue in the open ocean and investigated the cellular processes mediating Trichodesmium mortality in a large surface bloom from the New Caledonian lagoon (Spungin et al., 2016). Nutrient stress induced a PCD mediated crash of the Trichodesmium bloom. The filaments and colonies were characterized by upregulated expression of metacaspase genes, downregulated expression of gas-vesicle genes, enhanced TEP production and aggregation of the biomass (Spungin et al., 2016). Due to experimental conditions we could not measure the subsequent export and vertical flux of the dying biomass in the open ocean. Moreover, while the existence and role of PCD and its mediation of biogeochemical cycling of organic matter has been investigated in Trichodesmium, scarce information exists about PCD and other mortality pathways of most marine diazotrophs.

The OUTPACE (Oligotrophy to UITra-oligotrophy PACific Experiment) cruise was conducted from 18 February to 3 April 2015 along a west to east gradient from the oligotrophic area north of New Caledonia to the ultraoligotrophic western South Pacific gyre (French Polynesia). The goal of OUTPACE was to study the diazotrophic blooms and their fate within the oligotrophic ocean in the WTSP Ocean (Moutin et al., 2017). Our specific objective was to determine whether PCD was an important mechanism affecting diazotroph mortality and a factor regulating the fate of the blooms by mediation of vertical flux of organic matter. The strategy and experimental approach of the OUTPACE transect enabled sampling at three long duration (LD) stations of 5 days each (referred to as stations LDA, LDB and LDC) 
and provided 5-day snapshots into diazotroph physiology, dynamics and mortality processes. We specifically probed for the induction and operation of PCD and examined the relationship of PCD to the fate of organic matter and vertical flux from diazotrophs by the deployment of three sediment traps at 150,325 and $500 \mathrm{~m}$ depths.

\section{Methods}

\subsection{Sampling site and sampling conditions}

Sampling was conducted on a transect during austral summer (18 February-5 April 2015), on board the R/V L'Atalante (Moutin et al., 2017). Samples were collected from three long duration stations (LDA, LDB and LDC) where the ship remained for 5 days at each location and 15 short duration (SD 1-15) stations (approximately $8 \mathrm{~h}$ duration). The cruise transect was divided into two geographic regions. The first region (Melanesian archipelago, MA) included SD 1-12, LDA and LDB stations $\left(160-178^{\circ} \mathrm{E}\right.$ and $\left.170-175^{\circ} \mathrm{W}\right)$. The second region (subtropical gyre, GY) included SD 13-15 and LDC stations $\left(160-169^{\circ} \mathrm{W}\right)$.

\subsection{Chlorophyll $a$}

Samples for determination of Chl $a$ concentrations were collected by filtering $550 \mathrm{~mL}$ seawater on GF/F filters (Whatman, UK). Filters were frozen and stored in liquid nitrogen, and Chl $a$ was extracted in methanol and measured fluorometrically (Turner Designs Trilogy Optical kit) (Le Bouteiller et al., 1992). Satellite-derived surface Chl $a$ concentrations at the LD stations were used from before and after the cruise sampling at the LD stations. Satellite Chl $a$ data are added as supplementary video files (Supplement, Videos S1, S2, S3).

\subsection{Caspase-like and metacaspase activities}

Biomass was collected on $25 \mathrm{~mm}, 0.2 \mu \mathrm{m}$ pore-size polycarbonate filters and resuspended in $0.6-1 \mathrm{~mL}$ Lauber buffer (50 mM HEPES (pH 7.3), $100 \mathrm{mM} \mathrm{NaCl,} 10 \%$ sucrose, $0.1 \%$ (3-cholamidopropyl)-dimethylammonio-1propanesulfonate and $10 \mathrm{mM}$ dithiothreitol) and sonicated on ice (four cycles of $30 \mathrm{~s}$ each) using an ultracell disruptor (Sonic Dismembrator, Fisher Scientific, Waltham, MA, USA). Cell extracts were centrifuged $(10000 \times g$, 2 min, room temperature), and the supernatant was collected for caspase-like and metacaspase activity measurements. Caspase-like specific activity (normalized to total protein concentration) was determined by measuring the kinetics of cleavage for the fluorogenic caspase substrate Z-IETD-AFC (Z-Ile-Glu-Thr-Asp-AFC) at a $50 \mu \mathrm{M}$ final concentration (using Ex $400 \mathrm{~nm}$, Em $505 \mathrm{~nm}$; Synergy4 BioTek, Winooski, VT, USA), as previously described in Bar-Zeev et al. (2013). Metacaspase specific activity (normalized to total protein concentration) was determined by measuring the kinetics of cleavage for the fluorogenic metacaspase substrate AcVRPR-AMC (Ac-Val-Arg-Pro-Arg-AMC) (Tsiatsiani et al., 2011) at a $50 \mu \mathrm{M}$ final concentration (using Ex $380 \mathrm{~nm}$, Em $460 \mathrm{~nm}$; Synergy4 BioTek, Winooski, VT, USA). Relative fluorescence units were converted to protein-normalized substrate cleavage rates using AFC and AMC standards (Sigma) for caspase-like and metacaspase activities, respectively. Total protein concentrations were determined by Pierce ${ }^{\mathrm{TM}}$ BCA protein assay kit (Thermo Scientific product 23225).

\subsection{Phosphate analysis}

Seawater for phosphate $\left(\mathrm{PO}_{4}^{3-}\right.$, dissolved inorganic phosphorus) analysis was collected in $20 \mathrm{~mL}$ high-density polyethylene $\mathrm{HCl}$-rinsed bottles and poisoned with $\mathrm{HgCl}_{2}$ to a final concentration of $20 \mu \mathrm{g} \mathrm{L}-1$, stored at $4{ }^{\circ} \mathrm{C}$ until analysis. $\mathrm{PO}_{4}^{3-}$ was determined by a standard colorimetric technique using a segmented flow analyzer according to Aminot and Kérouel (2007) on a SEAL Analytical AA3 HR system 20 (SEAL Analytica, Serblabo Technologies, Entraiguessur-la-Sorgue, France). Quantification limit for $\mathrm{PO}_{4}^{3-}$ was $0.05 \mu \mathrm{mol} \mathrm{L}^{-1}$.

\subsection{Particulate organic carbon and nitrogen}

Samples were filtered through pre-combusted $\left(4 \mathrm{~h}, 450^{\circ} \mathrm{C}\right)$ $\mathrm{GF} / \mathrm{F}$ filters (Whatman $\mathrm{GF} / \mathrm{F}, 25 \mathrm{~mm}$ ), dried overnight at $60^{\circ} \mathrm{C}$ and stored in a desiccator until further analysis. POC and PON were determined using a $\mathrm{CHN}$ analyzer Perkin Elmer (Waltham, MA, USA) 2400 Series II CHNS/O Elemental Analyzer after carbonate removal from the filters using overnight fuming with concentrated $\mathrm{HCl}$ vapor.

\subsection{Dissolved organic carbon (DOC) and total organic carbon (TOC)}

Samples were collected from the Niskin bottles in combusted glass bottles and were immediately filtered through precombusted $\left(24 \mathrm{~h}, 450^{\circ} \mathrm{C}\right)$ glass fiber filters (Whatman $\mathrm{GF} / \mathrm{F}, 25 \mathrm{~mm}$ ). Filtered samples were collected into glass precombusted ampoules that were sealed immediately after filtration. Samples were acidified with orthophosphoric acid $\left(\mathrm{H}_{3} \mathrm{PO}_{4}\right)$ and analyzed by high-temperature catalytic oxidation (HTCO) (Sugimura and Suzuki, 1988; Cauwet, 1994) on a Shimadzu TOC-L analyzer. TOC was determined as $\mathrm{POC}+\mathrm{DOC}$.

\subsection{Transparent exopolymeric particles}

Water samples $(100 \mathrm{~mL})$ were gently $(<150 \mathrm{mbar})$ filtered through a $0.45 \mu \mathrm{m}$ polycarbonate filter (GE Water \& Process Technologies). Filters were then stained with a solution of $0.02 \%$ alcian blue (AB) and $0.06 \%$ acetic acid (pH of 2.5), and the excess dye was removed by a quick deionized water rinse. Filters were then immersed in sulfuric acid $(80 \%)$ for 
$2 \mathrm{~h}$, and the absorbance $(787 \mathrm{~nm})$ was measured spectrophotometrically (CARY 100, Varian). AB was calibrated using a purified polysaccharide xanthan gum (GX) (Passow and Alldredge, 1995). TEP concentrations ( $\mu \mathrm{g}$ GX equivalents $\mathrm{L}^{-1}$ ) were measured according to Passow and Alldredge (1995). To estimate the role of TEP in C cycling, the total amount of TEP-C was calculated using the TEP concentrations at each depth, and the conversion of GX equivalents to carbon applying the revised factor of 0.63 based on empirical experiments from both natural samples from different oceanic areas and phytoplankton cultures (Engel, 2004).

\subsection{Diazotrophic abundance}

The full description of DNA extraction, primer design and qPCR analyses are described in detail in this issue (Stenegren et al., 2018). Briefly, $2.5 \mathrm{~L}$ of water from six to seven depths with declining surface irradiance light intensity (100, $75,54,36,10,1$ and $0.1 \%$ ) were sampled and filtered onto a $25 \mathrm{~mm}$ diameter Supor filter (Pall Corporation, PallNorden, AB Lund Sweden) with a pore size filter of $0.2 \mu \mathrm{m}$. Filters were stored frozen in pre-sterilized bead beater tubes (Biospec Bartlesville Ok, USA) containing $30 \mathrm{~mL}$ of 0.1 and $0.5 \mathrm{~mm}$ glass bead mixture. DNA was extracted from the filters using a modified protocol of the Qiagen DNAeasy plant kit (Moisander et al., 2008) and eluted in $70 \mu \mathrm{L}$. With the re-eluted DNA extracts ready, samples were analyzed using the qPCR instrument StepOnePlus (Applied Biosystems) and fast mode. Previously designed TaqMAN assays and oligonucleotides and standards were prepared in advance and followed according to described methods for the following cyanobacterial diazotrophs: Trichodesmium, UCYNA1, UCYN-A2, UCYN-B and Richelia symbionts of diatoms (het-1, het-2, het-3) (Stenegren et al., 2018; Church et al., 2005; Foster et al., 2007; Moisander et al., 2010; Thompson et al., 2012).

\subsection{Microscopy}

Samples for microscopy were collected in parallel from the same depth profiles for which nucleic acids were sampled as described in Stenegren et al. (2018). Briefly, two profiles were collected on days 1 and 3 at each LD station and immediately filtered onto a $47 \mathrm{~mm}$ diameter Poretics (Millipore, Merck Millipore, Solna, Sweden) membrane filter with a pore size of $5 \mu \mathrm{m}$ using a peristaltic pump. After, filtration samples were fixed with a $1 \%$ paraformaldehyde $(v / v)$ for $30 \mathrm{~min}$. prior to storing at $-20^{\circ} \mathrm{C}$. The filters were later mounted onto an oversized slide and examined under an Olympus BX60 microscope equipped with blue (460-490 nm) and green $(545-580 \mathrm{~nm})$ excitation wavelengths. Three areas $\left(0.94 \mathrm{~mm}^{2}\right)$ per filter were counted separately and values were averaged. When abundances were low, the entire filter (area of $1734 \mathrm{~mm}^{2}$ ) was observed and cells enumerated. Due to poor fluorescence, only Trichodesmium colonies and free filaments could be accurately enumerated by microscopy, and in addition the larger cell diameter Trichodesmium (Katagynemene pelagicum) was counted separately as these were often present (albeit at lower densities). Other cyanobacterial diazotrophs (e.g., Crocosphaera watsonii-like cells, the Richelia symbionts of diatoms) were present but with poor fluorescence and could only be qualitatively noted.

\subsection{Particulate matter from sediment traps}

Particulate matter export was quantified with three PPS5 sediment traps $\left(1 \mathrm{~m}^{2}\right.$ surface collection, Technicap, France) deployed for 5 days at 150, 325 and $500 \mathrm{~m}$ at each LD station. Particle export was recovered in polyethylene flasks screwed on a rotary disk which allowed flasks to be changed automatically every $24 \mathrm{~h}$ to obtain a daily material recovery. The flasks were previously filled with a buffered solution of formaldehyde (final concentration of $2 \%$ ) and were stored at $4{ }^{\circ} \mathrm{C}$ until analysis to prevent degradation of the collected material. The flask corresponding to the fifth day of sampling on the rotary disk was not filled with formaldehyde to collect "fresh particulate matter" for further diazotroph quantification. Exported particulate matter was weighed and analyzed on EAIRMS (Integra2, Sercon Ltd) to quantify exported particulate carbon (PC) and particulate nitrogen (PN).

\subsection{Diazotroph abundance in the traps}

Triplicate aliquots of $2-4 \mathrm{~mL}$ from the flask dedicated for diazotroph quantification were filtered onto $0.2 \mu \mathrm{m}$ Supor filters, flash frozen in liquid nitrogen and stored at $-80^{\circ} \mathrm{C}$ until analysis. Nucleic acids were extracted from the filters as described in Moisander et al. (2008) with a 30 s reduction in the agitation step in a FastPrep cell disruptor (Thermo, model FP120; Qbiogene, Inc., France) and an elution volume of $70 \mu \mathrm{L}$. Diazotroph abundance for Trichodesmium spp., UCYN-B, UCYN-A1, het-1 and het- 2 was quantified by qPCR analyses on the nifH gene using previously described oligonucleotides and assays (Foster et al., 2007; Church et al., 2005). qPCR was conducted using a StepOnePlus system (applied Biosystems, Life Technologies, Stockholm Sweden) with the following parameters: $50^{\circ} \mathrm{C}$ for $2 \mathrm{~min}, 95^{\circ} \mathrm{C}$ for $10 \mathrm{~min}$ and 45 cycles of $95^{\circ} \mathrm{C}$ for $15 \mathrm{~s}$, followed by $60^{\circ} \mathrm{C}$ for $1 \mathrm{~min}$. Gene copy numbers were calculated from the mean cycle threshold $(\mathrm{Ct})$ value of three replicates and the standard curve for the appropriate primer and probe set. For each primer and probe set, duplicate standard curves were made from 10-fold dilution series ranging from $10^{8}$ to 1 gene copies per reaction. The standard curves were made from linearized plasmids of the target nifH or from synthesized gBLocks gene fragments (IDT technologies, Cralville, Iowa, USA). Regression analyses of the results ( $\mathrm{Ct}$ is the number of cycles) of the standard curves were analyzed in Excel. For the no template controls (NTCs), $2 \mu \mathrm{L}$ of $5 \mathrm{KDa}$ filtered 
nuclease-free water was used. No nifH copies were detected for any target in the NTC. In some samples only one or two of the three replicates produced an amplification signal; these were noted as detectable but not quantifiable. A fourth replicate was used to estimate the reaction efficiency for the Trichodesmium and UCYN-B targets as previously described in Short et al. (2004). Seven and two samples were below $95 \%$ in reaction efficiency for Trichodesmium and UCYN-B, respectively. The detection limit for the qPCR assays is $1-10$ copies.

\subsection{Statistical analyses}

A Spearman correlation coefficient test was applied to examine the strength of association between two variables and the direction of the relationship.

\section{Results and discussion}

\subsection{Diazotrophic characteristics and abundance in the LD stations}

The sampling strategy of the transect was planned so that changes in abundance and fate of diazotrophs could be followed in LD stations where measurements were taken from the same water mass (and location) over 5 days and drifting sediment traps were deployed (Moutin et al., 2017). Although rates for the different parameters were obtained for 5 days, this period is still a "snapshot" in time with the processes measured influenced by preceding events also continuing after the ship departed. Specifically, production of photosynthetic biomass (as determined from satellitederived $\mathrm{Chl} a$ ) and development of surface phytoplankton blooms, including cyanobacterial diazotrophs, displayed specific characteristics for each of the LD stations. We first examined the satellite-derived surface $\mathrm{Chl} a$ concentrations by looking at changes around the LD stations before and after our 5-day sampling at each station (daily surface $\mathrm{Chl} a$, $\mathrm{mg} \mathrm{m}^{-3}$ ) (Supplement, Videos S1, S2, S3).

At LDA, satellite data confirmed high concentrations of Chl $a$ indicative of intense surface blooms $\left(\sim 0.55 \mu \mathrm{g} \mathrm{L}^{-1}\right)$ between 8 and 19 February 2015 which began to gradually decline with over $60 \% \mathrm{Chl} a$ reduction until day 1 at the station (Supplement, Video S1, Fig. 1a). By the time we reached LDA on 25 February 2015 (day 1) Chl $a$ concentrations averaged $\sim 0.2 \mu \mathrm{g} \mathrm{L}{ }^{-1} \mathrm{Chl} a$ at the surface (Fig. 1a) and remained steady for the next 5 days with $\mathrm{Chl} a$ values of $0.2 \mu \mathrm{g} \mathrm{L}^{-1}$ measured on day 5 (Fig. 1a). When looking for biomass at depth, the deep chlorophyll maximum (DCM) recorded at $\sim 80 \mathrm{~m}$ depth was characterized by Chl $a$ concentrations increasing from 0.3 to $0.5 \mu \mathrm{g} \mathrm{L}^{-1}$ between days 3 and 5, respectively (Fig. 1d). While the Chl $a$ values of the surface biomass decreased for approximately 1 week prior to our sampling at station, the $\mathrm{Chl} a$ concentrations measured at depth increased during the corresponding time.
In contrast to LDA, the satellite data from LDB confirmed the presence of a surface bloom for over 1 month prior to our arrival at the station on 15 March 2015 (day 1) (Supplement, Video S2, Fig. 1b). This bloom was characterized by high surface $\mathrm{Chl} a$ concentrations $\left(\sim 0.6 \mu \mathrm{g} \mathrm{L}^{-1}\right.$, Supplement, Video S2) and on day 1 at the station surface Chl $a$ was $0.6 \mu \mathrm{L}^{-1}$ (Fig. 1b). Surface Chl $a$ then decreased over the next days at the station with a $50 \%$ reduction of Chl $a$ concentration from the sea surface $(5 \mathrm{~m})$ on day $5\left(0.3 \mu \mathrm{g} \mathrm{L}{ }^{-1}\right)$ (Fig. 1e). Thus, it appears that our 5 sampling days at LDB were tracking a surface bloom that had only began to decline after day 3 and continued to decrease $\left(\sim 0.1 \mu \mathrm{g} \mathrm{L}^{-1}\right)$ also after we had left the station (Fig. 1b). On day 1 of sampling, the DCM at LDB was relatively shallow, at $40 \mathrm{~m}$ with Chl $a$ values of $0.5 \mu \mathrm{g} \mathrm{L}^{-1}$. By day 5 the DCM had deepened to $80 \mathrm{~m}$ (de Verneil et al., 2017).

LDC was located in a region of extreme oligotrophy within the Cook Islands territorial waters (GY waters). This station was characterized historically $(\sim 4$ weeks before arrival) by extremely low $\mathrm{Chl} a$ concentrations at the surface $\left(\sim 0.02 \mu \mathrm{g} \mathrm{L}^{-1}\right.$, Supplement, Video S3) that were an order of magnitude lower than average $\mathrm{Chl} a$ measured at LDA and LDB. These values remained low with no significant variability for the 5 days at station or later (Fig. 1f) (Supplement, Video S3, Fig. 1c). Similar to the results from LDA, the DCM at LDC was found near the bottom of the photic layer at $\sim 135 \mathrm{~m}$, with Chl $a$ concentrations about 10-fold higher than those measured at surface with $\sim 0.2 \mu \mathrm{g} \mathrm{L}^{-1}$ (Fig. 1f).

Chl $a$ is an indirect proxy of photosynthetic biomass and we thus needed to ascertain who the dominant players (specifically targeting diazotrophic populations) were at each of the LD stations. Moreover, at LDA and LDB diazotrophic composition and abundance as determined by qPCR analysis were quite similar. At LDA Trichodesmium was the most abundant diazotroph, ranging between $6 \times 10^{4}$ and $1 \times 10^{6}$ nifH copies $\mathrm{L}^{-1}$ in the upper water column $(0-70 \mathrm{~m})$. UCYN-B (genetically identical to Crocosphaera watsonii) co-occurred with Trichodesmium between 35 and $70 \mathrm{~m}$, and het- 1 specifically identified the DDA between the diatom Rhizosolenia and the heterocystous diazotroph Richelia was observed only at the surface waters at $4 \mathrm{~m}$. UCYN-B and het-1 abundances were relatively lower than Trichodesmium abundances with $2 \times 10^{2}$ and $3 \times 10^{3}$ nifH copies $\mathrm{L}^{-1}$, respectively (Stenegren et al., 2018). Microscopic observations from LDA indicated that near the surface Rhizosolenia populations were already showing signs of decay since the silicified cell-wall frustules were broken and free filaments of Richelia were observed (Fig. 2e-f) (Stenegren et al., 2018). DDAs are significant $\mathrm{N}_{2}$ fixers in the oligotrophic oceans. Although their abundance in the WTSP is usually low, they are common and highly abundant in the New Caledonian lagoon significantly impacting $\mathrm{C}$ sequestration and rapid sinking (Turk-Kubo et al., 2015).

At LDB, Trichodesmium was also the most abundant diazotroph with nifH copies $\mathrm{L}^{-1}$ ranging between $1 \times 10^{4}$ and 

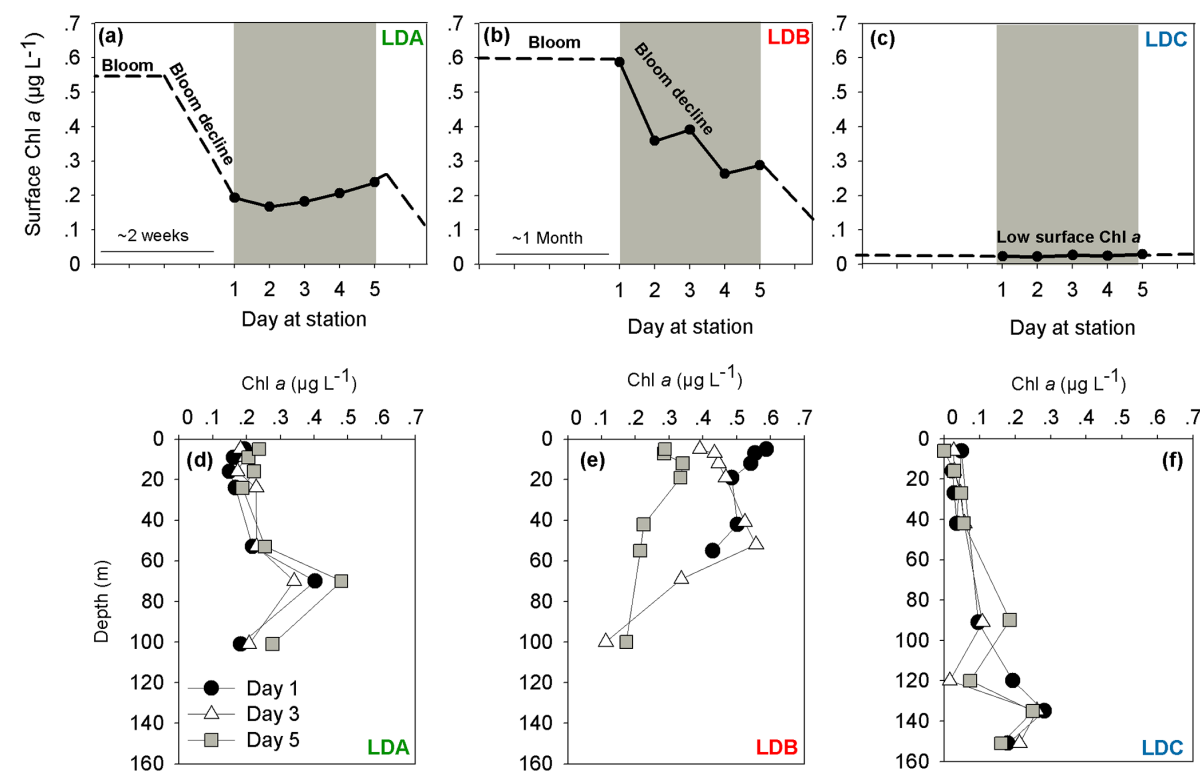

Figure 1. Temporal dynamics of surface chlorophyll $a(\mathrm{Chl} a$ ) concentrations in the long duration (LD) stations (a) LDA, (b) LDB and (c) LDC station. Chl $a$ was measured over 5 days at each station (marked in grey). Satellite data of daily surface Chl $a$ (mg m ${ }^{-3}$ ) around the LD stations of OUTPACE were used to predict changes in photosynthetic biomass before and after our measurements at the station (marked as dashed lines). Satellite data videos are added as supplementary data (Supplement, Videos S1, S2, S3). Chl $a$ profiles in (d) LDA, (e) LDB and (f) LDC. Measurements of Chl $a$ were taken on days 1 (black dot), 3 (white triangle) and 5 (grey square).

$5 \times 10^{5}$ within the top $60 \mathrm{~m}$ (Stenegren et al., 2018). Microscopical analyses confirmed high abundance of free filaments of Trichodesmium at LDB, while colonies were rarely observed (Stenegren et al., 2018). Observations of poor cell integrity were reported for most collected samples, with filaments at various stages of degradation and colonies under possible stress (Fig. 2a-d). In addition to Trichodesmium, UCYN-B was the second most abundant diazotroph ranging between $1 \times 10^{2}$ and $2 \times 10^{3}$ nifH copies $\mathrm{L}^{-1}$. Other unicellular diazotrophs of the UCYN groups (UCYN-A1 and UCYN-A2) were the least detected diazotrophs (Stenegren et al., 2018). Of the three heterocystous cyanobacterial symbiont lineages (het-1, het-2, het-3), het-1 was the most dominant $\left(1 \times 10^{1}-4 \times 10^{3}\right.$ nifH copies $\left.\mathrm{L}^{-1}\right)$ (Stenegren et al., 2018). Microscopic analyses from LDB demonstrated the cooccurrence of degrading diatom cells, mainly belonging to Rhizosolenia (Stenegren et al., 2018) (Fig. 2e-f).

In contrast to LDA and LDB, at LDC the highest nifH copy numbers (up to $6 \times 10^{5}$ nifH copies $\mathrm{L}^{-1}$ ) at $60 \mathrm{~m}$ depth were from the unicellular diazotrophs UCYN-B (Stenegren et al., 2018). Trichodesmium was only detected at $60 \mathrm{~m}$ and with very low copy numbers of nifH $\left(\sim 7 \times 10^{2}\right.$ nifH copies $\left.\mathrm{L}^{-1}\right)$ (Stenegren et al., 2018).

Corresponding to the physiological status of the bloom, higher $\mathrm{N}_{2}$ fixation rates $\left(45.0 \mathrm{nmol} \mathrm{NL}^{-1} \mathrm{~d}^{-1}\right)$ were measured in the surface waters $(5 \mathrm{~m})$ of LDB in comparison with those measured at LDA and LDC $\left(19.3 \mathrm{nmol} \mathrm{N} \mathrm{L}^{-1} \mathrm{~d}^{-1}\right.$ in LDA and below the detection limit at LDC at $5 \mathrm{~m}$ ) (Caffin et al., 2018).

\subsection{Diazotrophic bloom demise in the LD stations}

Of the three long duration stations we examined, LDA and LDB had a higher biomass of diazotrophs during the 5 days of sampling (Sect. 3.1). Our analyses examining bloom dynamics from the satellite-derived $\mathrm{Chl} a$ concentrations indicate a declining trend in chlorophyll-based biomass during the sampling time period. However, both LDA and LDB were still characterized by high (and visible to the eye at surface) biomass on the first sampling day at each station (day 1) as determined by qPCR and microscopy (Stenegren et al., 2018). This is different from LDC where biomass was extremely limited, and no clear evidence was obtained for any specific bloom or bloom demise. We therefore show results mostly from LDA and LDB and focus specifically on the evidence for PCD and diazotroph decline in areas with high biomass and surface blooms.

The causes of mortality at sea are difficult to discern as it most probably results from co-occurring processes including physical forces, chemical stressors, grazing, viral lysis and/or PCD. Here, we specifically focused on evidence for PCD and whether the influence of zooplankton grazing on the diazotrophs and especially on Trichodesmium at LDA and LDB impacted bloom dynamics. At LDA and LDB the total zooplankton population was generally low. Total zooplankton population at LDA ranged between 911 and 1900 individuals $\mathrm{m}^{-3}$ and in LDB between 1209 and 2188 individuals $\mathrm{m}^{-3}$ on day 1 and day 5, respectively. Trichodesmium is toxic and inedible to most zooplankton excluding three 


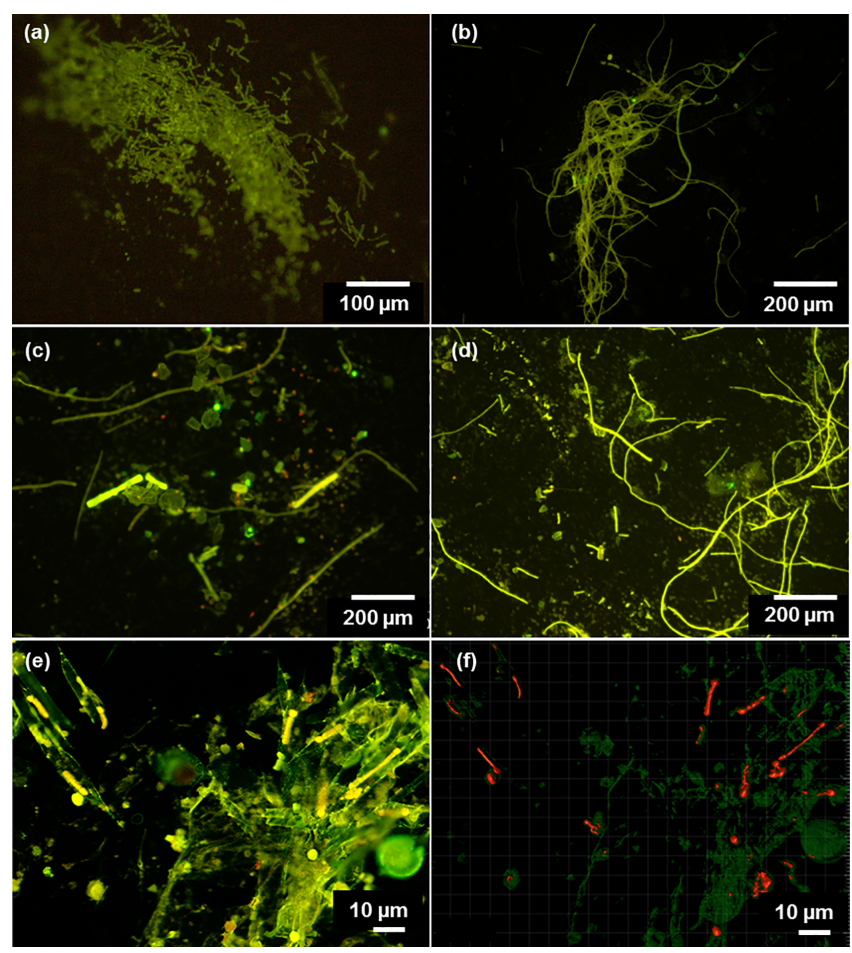

Figure 2. (a-d) Microscopic images of Trichodesmium from LDA and LDB. Observations of poor cell integrity were reported for collected samples, with filaments at various stages of degradation and colony under possible stress. (e) Confocal and (f) processed IMARIS images of Rhizosolenia-Richelia symbioses (het-1) at $6 \mathrm{~m}$ (75\% surface incidence). Green fluorescence indicates the chloroplast of the diatoms, and red fluorescence are the Richelia filaments; Microscopic observations indicate that near the surface Rhizosolenia populations were already showing signs of decay since the silicified cell-wall frustules were broken and free filaments of Richelia were observed.

species of harpacticoid zooplankton - Macrosetella gracilis, Miracia efferata and Oculosetella gracilis (O'Neil and Roman, 1994). During our sampling days at these stations, Macrosetella gracilis a specific grazer of Trichodesmium comprised less than $1 \%$ of the total zooplankton community with another grazer Miracia efferata comprising less than $0.1 \%$ of total zooplankton community. Oculosetella gracilis was not found at these stations. The low number of harpacticoid zooplankton specifically grazing on $\mathrm{Tr} i$ chodesmium found in the LDA and LDB station refutes the possibility that grazing caused the massive demise of the bloom. Moreover, the toxicity of Trichodesmium to many grazers (Rodier and Le Borgne, 2008; Kerbrat et al., 2011) could critically limit the amount of Trichodesmium-derived recycled matter within the upper mixed layer.

Viruses have been increasingly invoked as key agents terminating phytoplankton blooms. Phages may infect Trichodesmium (Brown et al., 2013; Hewson et al., 2004; Ohki, 1999) yet they have not been demonstrated to terminate large surface blooms. Virus-like particles were previously enumerated from Trichodesmium samples during bloom demise, yet the numbers of virus-like particles did not indicate that a massive, phage-induced lytic event of Trichodesmium occurred there (Spungin et al., 2016). Virus infection may induce PCD by causing an increased production of reactive oxygen species (Vardi et al., 2012) which stimulates PCD in algal cells (Berman-Frank et al., 2004; Bidle, 2015; Thamatrakoln et al., 2012). Viral attack can also directly trigger PCD as part of an antiviral defense system (Bidle, 2015). Virus abundance and activity were not enumerated in this study, so unfortunately we cannot estimate their specific influence on mortality.

Limited availability of $\mathrm{Fe}$ and $\mathrm{P}$ induces $\mathrm{PCD}$ in Trichodesmium (Berman-Frank et al., 2004; Bar-Zeev et al., 2013). At LDA and LDB, Fe concentrations at the time of sampling were relatively high $(>0.5 \mathrm{nM})$, possibly due to island effects (de Verneil et al., 2017). Phosphorus availability, or lack of phosphorus, can also induce PCD (Berman-Frank et al., 2004; Spungin et al., 2016). $\mathrm{PO}_{4}^{3-}$ concentrations at the surface $(0-40 \mathrm{~m})$ of LDA and LDB stations were extremely low around $0.05 \mu \mathrm{mol} \mathrm{L}^{-1}$ (de Verneil et al., 2017), possibly consumed by the high biomass and high growth rates of the bloom causing nutrient stress and bloom mortality. $\mathrm{PO}_{4}^{3-}$ concentrations observed at LDC were above the quantification limit with average values of $0.2 \mu \mathrm{mol} \mathrm{L}^{-1}$ in the $0-150 \mathrm{~m}$ depths (data not shown). These limited $\mathrm{P}$ concentrations may curtail the extent of growth, induce PCD and pose an upper limit on biomass accumulation.

Here we compared, for the first time in oceanic populations, two PCD indices, caspase-like and metacaspase activities, to examine the presence/operation of PCD in the predominant phytoplankton (and diazotroph) populations along the transect. This was determined by the cleavage of $\mathrm{Z}$ IETD-AFC and Ac-VRPR-AMC substrates for caspase-like and metacaspase activities, respectively. As we are working with natural communities (and not with monospecific lab cultures), the activities presented here do not correspond to the purified protein, but to cell-free extracts. Thus it cannot point at the specific cell undergoing PCD or identify the specific organism responsible for the activity. Here we specifically show the results from LDA and LDB where biomass and activities were detectable.

Classic caspases are absent in phytoplankton, including in cyanobacteria, and are unique to metazoans and several viruses (Minina et al., 2017). In diverse phytoplankton the presence of a caspase domain suffices to demonstrate caspase-like proteolytic activity that occurs upon PCD induction when the caspase specific substrate Z-IETD-AFC is added (Berman-Frank et al., 2004; Bidle and Bender, 2008; Bar-Zeev et al., 2013). Cyanobacteria and many diazotrophs contain genes that are similar to caspases: the metacaspasescysteine proteases. These proteases share structural properties with caspases, specifically a histidine-cysteine catalytic dyad in the predicted active site (Tsiatsiani et al., 2011). 


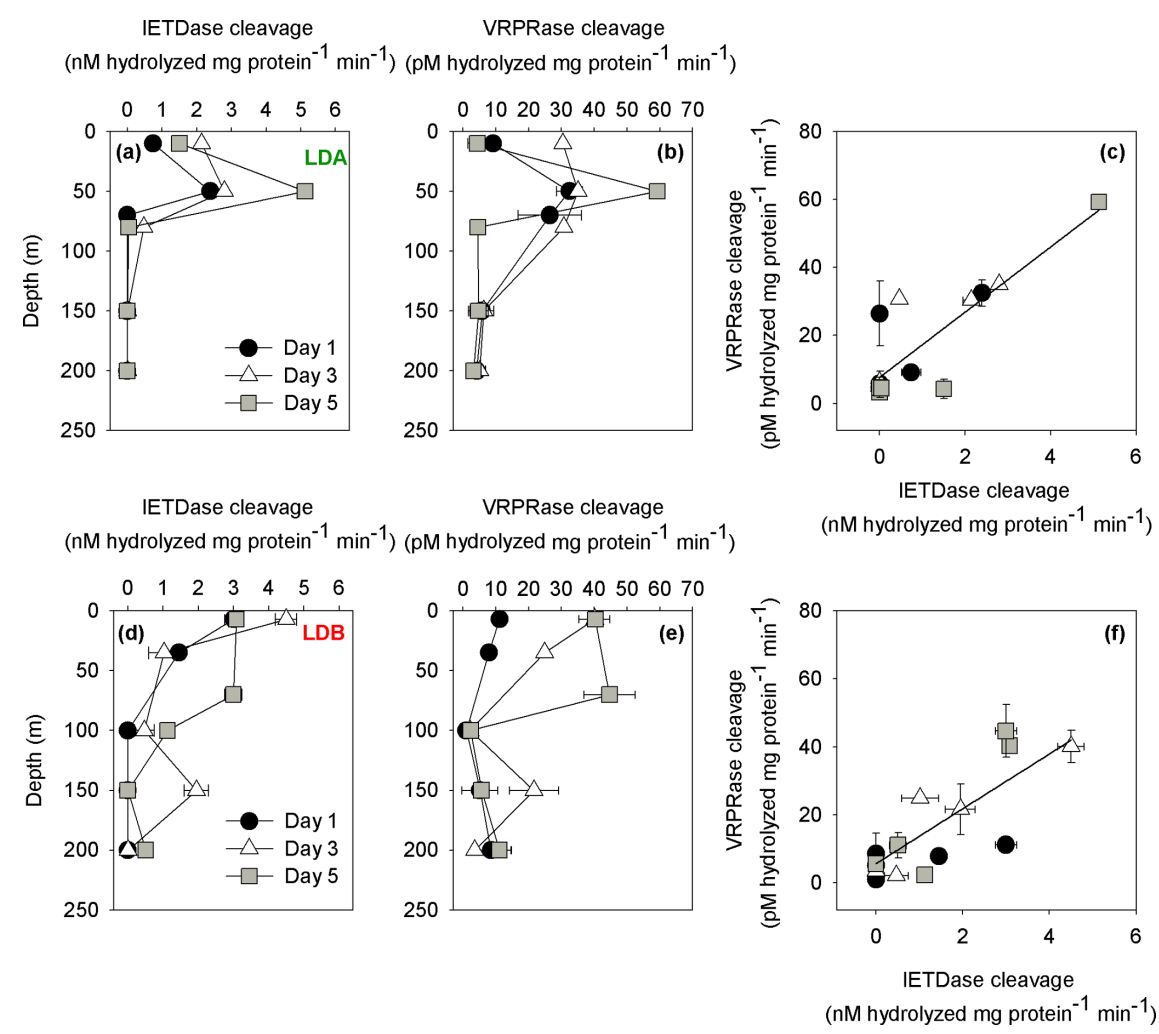

Figure 3. PCD indices from LDA and LDB. (a) Caspase-like activity from LDA (nM hydrolyzed mg protein ${ }^{-1} \mathrm{~min}^{-1}$ ) assessed by cleavage of the canonical fluorogenic substrate, Z-IETD-AFC. (b) Metacaspase activity from LDA (pM hydrolyzed $\mathrm{mg} \mathrm{protein}^{-1} \mathrm{~min}^{-1}$ ) assessed by cleavage of the canonical fluorogenic substrate, Ac-VRPR-AMC. (c) Relationship between caspase-like activity and metacaspase activity from LDA $(r=0.7, n=15, p=0.005)$. (d) Caspase-like activity rates in LDB station (nM hydrolyzed $\mathrm{mg} \mathrm{protein}^{-1} \mathrm{~min}^{-1}$ ). (e) Metacaspase activity in LDB station (pM hydrolyzed $\mathrm{mg}_{\text {protein }}{ }^{-1} \mathrm{~min}^{-1}$ ). (f) Relationship between caspase-like activity and metacaspase activity in LDB station $(r=0.7, n=15, p=0.001)$. Caspase-like and metacaspase activities at LDA and LDB stations were measured on days 1 (black dot), 3 (white triangle) and 5 (grey square) between surface and $200 \mathrm{~m}$. Error bars represent \pm 1 standard deviation $(n=3)$.

While the specific role and function of metacaspases genes are unknown, and cannot be directly linked to gene expression, preliminary investigations have indicated that when PCD is induced some of these genes are upregulated (Bidle and Bender, 2008; Spungin et al., 2016).

Of the abundant diazotrophic populations at LDA and LDB 12 metacaspases have previously been identified in Trichodesmium spp. (Asplund-Samuelsson et al., 2012; Asplund-Samuelsson, 2015; Jiang et al., 2010; Spungin et al., 2016). Phylogenetic analysis of a wide diversity of truncated metacaspase proteins, containing the conserved and characteristic caspase super family (CASc; c100042) domain structure, revealed metacaspase genes in both Richelia intracellularis (het-1) from the DDA and Crocosphaera watsonii (a cultivated unicellular cyanobacterium), which is genetically identical to the UCYN-B nifH sequences (D. Spungin et al., unpublished data).

We compared between metacaspase and caspase-like activities for the $>0.2 \mu \mathrm{m}$ fraction sampled assuming that the greatest activity would be due to the principle organisms contributing to the biomass - i.e., the diazotrophic cyanobacteria. Caspase-like activity and metacaspase activity were specifically measured at all LD stations (days 1 , $3,5)$ at five depths between 0 and $200 \mathrm{~m}$. Caspase-like activity at the surface waters $(50 \mathrm{~m})$ at LDA, as determined by the cleavage of IETD-AFC substrate, was between 2.3 and $2.8 \pm 0.1 \mathrm{nM}$ hydrolyzed $\mathrm{mg}$ protein ${ }^{-1} \mathrm{~min}^{-1}$ on days 1 and 3, respectively (Fig. 3a). The highest activity was measured on day 5 at $50 \mathrm{~m}$ with $5.1 \pm 0.1 \mathrm{nM}$ hydrolyzed mg protein ${ }^{-1} \min ^{-1}$. Similar trends were obtained at LDA for metacaspase activity as measured by the cleavage of the VRPR-AMC substrate, containing an Arg residue at the $\mathrm{P} 1$ position, specific for metacaspase cleavage (Tsiatsiani et al., 2011). High metacaspase activities were measured on days 1 and $3(50 \mathrm{~m})$ with $32 \pm 4$ and $35 \pm 0.2 \mathrm{pM}$ hydrolyzed $\mathrm{mg}$ protein ${ }^{-1} \mathrm{~min}^{-1}$, respectively (Fig. 3b). The highest metacaspase activity was measured on day 5 at $50 \mathrm{~m}$ with $59 \pm 1$ pM hydrolyzed mg protein ${ }^{-1} \mathrm{~min}^{-1}$ with declining activity at greater depths (Fig. 3b).

Caspase-like activity at LDB, was similar for all sampling days, with the highest activity recorded 

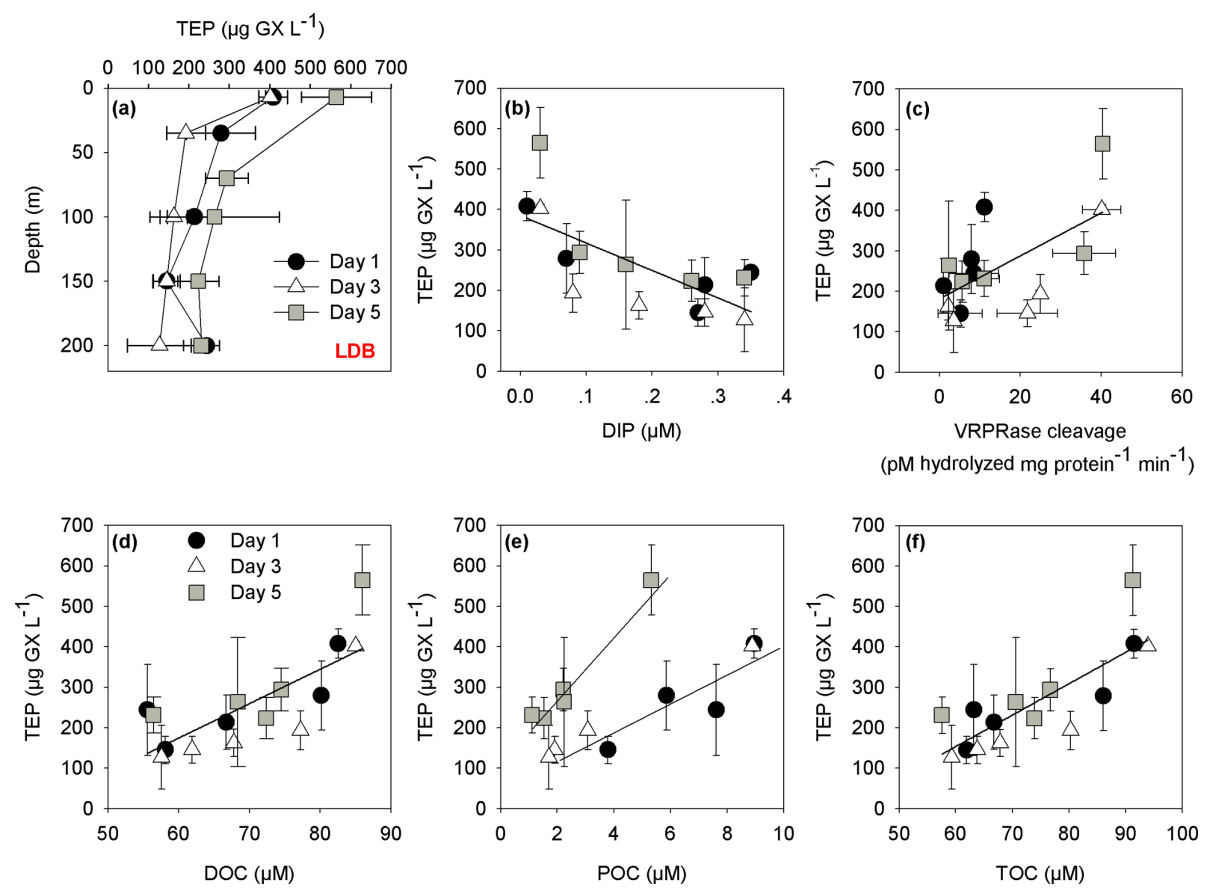

Figure 4. (a) Depth profiles of TEP concentrations $\left(\mu \mathrm{g} \mathrm{GXL}{ }^{-1}\right)$ at LDB station. Measurements were taken on days 1,3 and 5 at the station at surface-200 m depths. (b) The relationships between the concentration of transparent exopolymeric particles (TEP) ( $\mu \mathrm{g}$ GX $\mathrm{L}^{-1}$ ) and dissolved inorganic phosphorus (DIP) $(\mu \mathrm{M})$ for days 1,3 and 5 at the LDB station $(r=-0.7, n=15, p=0.005)$. (c) The relationships between the concentration of TEP $\left(\mu \mathrm{g} \mathrm{GXL}{ }^{-1}\right)$ and metacaspase activity (pmol hydrolyzed mg protein ${ }^{-1} \min ^{-1}$ ) for days 1,3 and 5 at the LDB assessed by cleavage of the canonical fluorogenic substrate, Ac-VRPR-AMC ( $r=0.6, n=15, p=0.03$ ); (d) The relationship between the concentration of TEP $\left(\mu \mathrm{g} \mathrm{GX} \mathrm{L}^{-1}\right)$ and dissolved organic carbon $(\mathrm{DOC})(\mu \mathrm{M})$ for days 1,3 and 5 at the LDB station $(r=0.7, n=15$, $p=0.004)$ (e) The relationship between the concentration of TEP $\left(\mu \mathrm{gX} \mathrm{G}{ }^{-1}\right)$ and particulate organic carbon (POC) ( $\left.\mu \mathrm{M}\right)$ for days 1,3 and 5 at the LDB station $(r=0.8, n=5, p=0.1$ for day 1 and $r=0.9, n=8, p=0.002$ for day 3 and 5). (f) The relationship between the concentration of TEP $\left(\mu \mathrm{g} \mathrm{GX} \mathrm{L}^{-1}\right)$ and total organic carbon (TOC) $(\mu \mathrm{M})$ for days 1,3 and 5 at the LDB station $(r=0.7, n=15, p=0.001)$. Measurements were taken on days 1 (black dot), 3 (white triangle) and 5 (grey square) at LDB at five depths between surface and $200 \mathrm{~m}$. Error bars for TEP represent \pm 1 standard deviation $(n=3)$.

from the surface samples (ranging from $3 \pm 0.2$ to $4.5 \pm 0.3 \mathrm{nM}$ hydrolyzed $\mathrm{mg}$ protein ${ }^{-1} \mathrm{~min}^{-1}$ at $7 \mathrm{~m}$ depth and then decreasing with depth) (Fig. 3d). On day 3 caspase-like activity at LDB increased at the surface with $4.5 \pm 0.3 \mathrm{nM}$ hydrolyzed $\mathrm{mg}$ protein ${ }^{-1} \mathrm{~min}^{-1}$ and then declined slightly by day 5 back to $3 \pm 0.2 \mathrm{nM}$ hydrolyzed $\mathrm{mg}$ protein ${ }^{-1} \mathrm{~min}^{-1}$. The decrease in activity at the surface between days 3 and 5 was accompanied by an increase in caspase-like activity measured in the DCM between days 3 and 5 (Fig. 3d). Caspase-like activity at the DCM on day $3(35 \mathrm{~m})$ was $1 \pm 0.4 \mathrm{nM}$ hydrolyzed mg protein ${ }^{-1} \mathrm{~min}^{-1}$ and by day 5 had increased to $3 \pm 0.2 \mathrm{nM}$ hydrolyzed $\mathrm{mg}$ protein ${ }^{-1} \mathrm{~min}^{-1}$ for samples from $70 \mathrm{~m}$ depth. Thus, at LDB, caspase-like activity increased from days 1 to 5 and with depth. Higher activities were initially recorded at surface and then at depth and were coupled with the decline of the bloom (Fig. 3d). Similar trends were obtained at LDB for metacaspase activity with $11.1 \pm 0.9 \mathrm{pM}$ hydrolyzed $\mathrm{mg}$ protein ${ }^{-1} \mathrm{~min}^{-1}$ at the surface $(7 \mathrm{~m})$ on day 1 . A 4-fold increase in activity was measured at the surface on day 3 with
$40.1 \pm 5$ pM hydrolyzed mg protein ${ }^{-1} \min ^{-1}$ (Fig. 3e). Similar high activities were measured also on day 5 (Fig. 3e). However, the increase in activity was also pronounced at depth of $\sim 70 \mathrm{~m}$ and not only at the surface. Metacaspase activity on day 5 was the highest with $40.3 \pm 0.5$ and $44.6 \pm 8 \mathrm{pM}$ hydrolyzed $\mathrm{mg}$ protein ${ }^{-1} \mathrm{~min}^{-1}$ at 7 and $70 \mathrm{~m}$, respectively (Fig. 3e). The relatively low metacaspase activity measured on day 1 appears to correspond with the stressed physiological status of the biomass just prior to increased mortality rates. Metacaspase activity increased correspondingly with the pronounced decline in $\mathrm{Chl} a$ from day 1 to day 5 (Fig. 1b).

Metacaspase and caspase-like activities are significantly and positively correlated at LDA and LDB $(r=0.7, p=$ 0.005 and $r=0.7, p=0.001$ for LDA and LDB, respectively) (Fig. $3 \mathrm{c}$ and $\mathrm{f}$ ). As our experiments find a significant positive correlation between both activities, we performed a series of inhibitor experiments to test whether metacaspases are substrate specific and are not the caspase-like activity we have examined (D. Spungin et al., unpublished data). In vitro treatment with a protease inhibitor (antipain dihydrochlo- 
Table 1. Temporal changes in the relative composition $(w / w)$ and distribution of TEP, TEP-C and organic carbon and nitrogen fractions within the water column during days 1,3 and 5 in the LDA station at different depths, ranging between surface $(10 \mathrm{~m})$ and $200 \mathrm{~m}$.

\begin{tabular}{lrrrrrrr}
\hline Day at LDA station & Depth $(\mathrm{m})$ & TEP $\left(\mu \mathrm{g} \mathrm{GXL}^{-1}\right)$ & TEP-C & \%TEP-C & POC $(\mu \mathrm{M})$ & TOC $(\mu \mathrm{M})$ & POC / PON \\
\hline 1 & 10 & $241 \pm 40$ & 152.3 & 14.5 & 9.21 & 87.4 & 8 \\
& 50 & $562 \pm 7$ & 354.3 & 41.9 & 2.47 & 70.5 & 13 \\
& 70 & $87 \pm 17$ & 54.8 & 6.7 & 2.93 & 68.7 & 11 \\
& 150 & $\mathrm{ND}$ & $\mathrm{ND}$ & $\mathrm{ND}$ & 3.18 & 61.1 & 13 \\
& 200 & $296 \pm 135$ & 186.5 & 27.2 & 3.04 & 57.2 & 5 \\
\hline 3 & 10 & $126 \pm 2$ & 79.6 & 8.3 & 3.60 & 79.7 & 12 \\
& 80 & 263 & 166.1 & 20.5 & 4.62 & 67.5 & 15 \\
& 150 & $144 \pm 54$ & 91.2 & 12.9 & 2.22 & 59.0 & 22 \\
& 200 & $191 \pm 13$ & 120.9 & 18.6 & 1.29 & 54.2 & 27 \\
\hline 5 & 10 & $\mathrm{ND}$ & $\mathrm{ND}$ & $\mathrm{ND}$ & 5.80 & 83.7 & 7 \\
& 50 & $348 \pm 60$ & 219.5 & 26.8 & 3.33 & 68.3 & 6 \\
& 80 & 146 & 92.2 & 12.1 & 4.91 & 63.3 & 8 \\
& 150 & 220 & 138.6 & 18.0 & 2.72 & 58.2 & 7 \\
& 200 & 200 & 126 & 21.3 & 2.84 & 54.2 & 236 \\
\hline
\end{tabular}

Abbreviations: TEP is transparent exopolymeric particle; TEP-C is TEP carbon; POC is particulate organic C; TOC is total organic C; ND indicates no data.

ride) efficiently inhibited metacaspase activity, confirming the arginine-based specificity of Trichodesmium. Our biochemical activity and inhibitor observations demonstrate that metacaspases and caspases-like activities are likely distinct and are independently activated under stress and coupled to PCD in our experiments of both laboratory and field populations. However, caspase-like activity was somewhat sensitive to the inhibitor (antipain dihydrochloride), showing a $\sim 30$ $40 \%$ drop in activity. This hints at some catalytic crossover between these two catalytic activities in Trichodesmium that further should be studied. We do not know which protein is responsible for the caspase-like specific activities and which drivers regulate it. However, the tight correlation between both activities, specifically for Trichodesmium, and here at LDA and LDB suggests that both activities occur in the cell when PCD is induced. To date, we are not aware of any previous studies examining metacaspase or caspase-like activity (or the existence of PCD) in DDA such as RhizosoleniaRichelia.

\subsection{TEP dynamics and carbon pools}

TEP link between the particulate and dissolved carbon fractions and act to augment the coagulation of colloidal precursors from the dissolved organic matter and from biotic debris and to increase vertical carbon flux (Passow, 2002; Verdugo and Santschi, 2010). TEP production also increases upon PCD induction - specifically in large bloom-forming organisms such as Trichodesmium (Berman-Frank et al., 2007; Bar-Zeev et al., 2013).

At LDA, TEP concentrations at $50 \mathrm{~m}$ depth were highest on day 1 with measured concentrations of $562 \pm 7 \mu \mathrm{g} \mathrm{GXL}^{-1}$ (Table 1) that appear to correspond with the declining physiological status of the cells that were sampled at that time (Fig. 2a-d). TEP concentrations during days 3 and 5 decreased to less than $350 \mu \mathrm{g} \mathrm{GXL}{ }^{-1}$, and it is possible that most of the TEP had been formed and sank prior to our measurements in the LDA station.

At LDB, TEP concentrations on days 1 and 3 were similar with $\sim 400 \mu \mathrm{g} \mathrm{GX} \mathrm{L}^{-1}$ at the surface $(7 \mathrm{~m})$ while concentrations decreased about 2-fold with depth, averaging at $220 \pm 56$ and $253 \pm 32 \mu \mathrm{g} \mathrm{GXL}^{-1}(35-200 \mathrm{~m})$ for day 1 and 3, respectively (Fig. 4a, Table 2). A significant $(>150 \%)$ increase in TEP concentrations was observed on day 5 compared to previous days, with TEP values of $565 \pm 87 \mu \mathrm{g} \mathrm{GXL}^{-1}$ at the surface $(7 \mathrm{~m}$ ) (Fig. $4 \mathrm{a}$, Table 2). Although TEP concentrations were elevated at surface, the difference in averaged TEP concentrations observed at the deeper depths $(35-200 \mathrm{~m})$ between day 3 $\left(157 \pm 28 \mu \mathrm{g} \mathrm{GX} \mathrm{L}^{-1}\right)$ and day $5\left(253 \pm 32 \mathrm{GXL}^{-1}\right)$ indicated that TEP from the surface was either breaking down or sinking to depth (Fig. 4a, Table 2). The TEP concentrations from this study correspond with values and trends reported from other marine environments (Engel, 2004; BarZeev et al., 2009) and specifically with TEP concentrations measured from the New Caledonian lagoon (Berman-Frank et al., 2016).

TEP are produced by many phytoplankton including cyanobacteria under conditions uncoupling growth from photosynthesis (i.e., nutrient but not carbon limitation) (Berman-Frank and Dubinsky, 1999; Passow, 2002; BermanFrank et al., 2007). Decreasing availability of dissolved nutrients such as nitrate and phosphate has been significantly correlated with increase in TEP concentrations in both cultured phytoplankton and natural marine systems (Bar-Zeev et al., 2013; Brussaard et al., 2005; Engel et al., 2002; Urbani 
Table 2. Temporal changes in the relative composition $(w / w)$ and distribution of TEP, TEP-C and organic carbon and nitrogen fractions within the water column during days 1, 3 and 5 in the LDB station at different depths, ranging between surface $(7 \mathrm{~m})$ and $200 \mathrm{~m}$.

\begin{tabular}{lrrrrrrr}
\hline Day at LDB station & Depth $(\mathrm{m})$ & TEP $\left(\mu \mathrm{g} \mathrm{GX}^{-1}\right)$ & TEP-C & \% TEP-C & POC $(\mu \mathrm{M})$ & TOC $(\mu \mathrm{M})$ & POC $/$ PON \\
\hline 1 & 7 & $408 \pm 36$ & 257.1 & 23.4 & 8.95 & 91.5 & 6.0 \\
& 35 & $279 \pm 86$ & 175.9 & 17.0 & 5.86 & 86.0 & 9.1 \\
& 100 & $214 \pm 67$ & 134.7 & 16.8 & $\mathrm{ND}$ & 66.7 & ND \\
& 150 & $145 \pm 34$ & 91.5 & 12.3 & 3.79 & 61.9 & 11.2 \\
& 200 & $244 \pm 113$ & 153.7 & 20.3 & 7.61 & 63.2 & 9.8 \\
\hline 3 & 7 & $402 \pm 12$ & 253.1 & 22.5 & 8.88 & 93.9 & 6.9 \\
& 35 & $193 \pm 48$ & 121.8 & 12.6 & 3.07 & 80.3 & 8.2 \\
& 100 & $163 \pm 33$ & 102.4 & 12.6 & ND & 67.8 & ND \\
& 150 & $145 \pm 34$ & 91.6 & 12.0 & 1.91 & 63.8 & 7.4 \\
& 200 & $127 \pm 79$ & 80.2 & 11.3 & 1.71 & 59.3 & 5.7 \\
\hline 5 & 7 & $565 \pm 87$ & 355.8 & 32.5 & 5.32 & 91.3 & 5.9 \\
& 70 & $294 \pm 53$ & 185.2 & 20.1 & 2.21 & 76.7 & 6.1 \\
& 100 & $264 \pm 160$ & 166.2 & 19.6 & 2.25 & 70.6 & 8.0 \\
& 150 & $224 \pm 51$ & 140.8 & 15.9 & 1.53 & 73.9 & 5.1 \\
\hline
\end{tabular}

Abbreviations: TEP is transparent exopolymeric particle; TEP-C is TEP carbon; POC is particulate organic C; TOC is total organic C; ND indicates no data.

et al., 2005). TEP production in Trichodesmium is enhanced as a function of nutrient stress (Berman-Frank et al., 2007).

In the New Caledonian coral lagoon TEP concentrations were significantly and negatively correlated with ambient concentrations of dissolved inorganic phosphorus (BermanFrank et al., 2016). Here, at LDB a significant negative correlation of TEP with dissolved inorganic phosphorus was also observed (Fig. 4b, $p=0.005$ ), suggesting that lack of phosphorus set a limit to continued biomass increase and stimulated TEP production in the nutrient-stressed cells. TEP production was also significantly and positively correlated with metacaspase activity at all days (Fig. 4c, $p=0.03$ ), further indicating that biomass undergoing PCD produced more TEP. In the diatom Rhizosolenia setigera TEP concentrations increased during the stationary-decline phase (Fukao et al., 2010) and could also affect buoyancy. Coupling between PCD and elevated production of TEP and aggregation has been previously shown in Trichodesmium cultures (BermanFrank et al., 2007; Bar-Zeev et al., 2013). Here we cannot confirm a mechanistic link between nutrient stress, PCD induction and TEP production, but show significant correlations between these parameters measured at LDA and LDB with the declining diazotroph blooms (Fig. 4c) (Spungin et al., 2016).

Furthermore, TEP concentrations at LDB were significantly and positively correlated with TOC, POC and DOC (Fig. 4d-f), confirming the integral part of TEP in the cycling of carbon at this station. Assuming a carbon content of $63 \%(w / w)$ (Engel, 2004), we estimate that TEP contributes to the organic carbon pool on the order of $\sim 80$ $356 \mu \mathrm{g} \mathrm{C} \mathrm{L}^{-1}$ (Tables 1 and 2) with the percentage of TEP-C from TOC ranging between 7 and $42 \%$ and between 11 and
$32 \%$ at LDA and LDB, respectively (Tables 1 and 2, taking into account spatial and temporal differences). Thus, at LDB, surface TEP-C increased from $22 \%$ on day 3 to $32 \%$ of the TOC content on day 5 . However, for the same time period a 2-fold increase of TEP was measured at $200 \mathrm{~m}$ (11 to $21 \%$ ). These results reflect the bloom status at LDB. During bloom development, organic $\mathrm{C}$ and $\mathrm{N}$ are incorporated to the cells and little biotic TEP production occurs while stationary growth (as long as photosynthesis continues) stimulates TEP production (Berman-Frank and Dubinsky, 1999). When mortality exceeds growth, the presence of large amounts of sticky TEP provide "hot spots" or substrates for bacterial activity and facilitate aggregation of particles and enhanced sinking rates of aggregates as previously observed for Trichodesmium (Bar-Zeev et al., 2013).

\subsection{Linking PCD-induced bloom demise to particulate $\mathrm{C}$ and $\mathrm{N}$ export}

Measurements of elevated rates of metacaspase and caspaselike activities and changes in TEP concentrations are not sufficient to link PCD and vertical export of organic matter as demonstrated for laboratory cultures of Trichodesmium (BarZeev et al., 2013). To see whether PCD-induced mortality led to enhanced carbon flux at sea we then examined mass flux and specific evidence for diazotrophic contributions from the drifting sediment traps $(150,325$ and $500 \mathrm{~m})$ at LDA and LDB stations.

Mass flux at LDA increased with time, with the maximal mass flux rates obtained from the $150 \mathrm{~m}$ trap (123 dry weight (DW) $\mathrm{m}^{-2} \mathrm{~d}^{-1}$ ) on day 4. The highest mass flux was 40 and $27 \mathrm{DW} \mathrm{m}^{-2} \mathrm{~d}^{-1}$ from the deeper sediment traps 
(325 and $500 \mathrm{~m}$ traps, respectively). PC and PN showed similar trends as the mass flux. At LDA, PC varied between 3.2 and $30 \mathrm{mg} \mathrm{sample}^{-1}$ and $\mathrm{PN}$ ranged from 0.3 to $3.2 \mathrm{mg} \mathrm{sample}^{-1}$ in the $150 \mathrm{~m}$ trap. At LDB, PC varied from 1.6 to $6 \mathrm{mg} \mathrm{sample}^{-1}$ and total PN ranged from 0.2 to $0.8 \mathrm{mg} \mathrm{sample} \mathrm{e}^{-1}$ in the $150 \mathrm{~m}$ trap. The total sediment flux in the traps deployed at LDB ranged between $6.4 \mathrm{mg} \mathrm{m}^{-2} \mathrm{~d}^{-1}$ (150 $\mathrm{m}$, day 4$)$ and $33.5 \mathrm{mg} \mathrm{m}^{-2} \mathrm{~d}^{-1}$ (500 $\mathrm{m}$, day 2 ), with an average of $18.9 \mathrm{mg} \mathrm{m}^{-2} \mathrm{~d}^{-1}$. Excluding the deepest trap at $500 \mathrm{~m}$ where the high flux occurred on day 2 , in the other traps the highest export flux rate occurred at the last day at the station (day 5).

Analyses of the community found in the sediment traps, as determined by qPCR from the accumulated matter on day 5 at the station, confirmed that Trichodesmium, UCYN-B and het-1 were the most abundant diazotrophs in the sediment traps at LDA and LDB stations (Caffin et al., 2018), significantly correlating with the dominant diazotrophs found at the surface of the ocean (measured on day 1). Trichodesmium and Rhizosolenia-Richelia association (het-1) were the major contributors to diazotroph export at LDA and LDB while UCYN-B and het-1 were the major contributors at LDC (Caffin et al., 2018). At LDA the deeper traps contained Trichodesmium with $2.6 \times 10^{7}$ and $1.4 \times 10^{7}$ nifH copies $\mathrm{L}^{-1}$ at the 325 and $500 \mathrm{~m}$ traps, respectively. UCYN$\mathrm{B}$ was detected in all traps with the highest abundance at the $325 \mathrm{~m}\left(4.2 \times 10^{6}\right.$ nifH copies $\left.\mathrm{L}^{-1}\right)$ and $500 \mathrm{~m}$ traps $\left(2.8 \times 10^{6}\right.$ nifH copies $\left.\mathrm{L}^{-1}\right)$. Het-1 was found only in the $325 \mathrm{~m}$ trap with $2.0 \times 10^{7}$ nifH copies $\mathrm{L}^{-1}$ (Fig. 5a). At LDB, Trichodesmium counts were detected in all traps, with $8.2 \times 10^{4}$ nifH copies $\mathrm{L}^{-1}$ in the $150 \mathrm{~m}$ trap and $3.4 \times 10^{6}$ and $8 \times 10^{6}$ nifH copies $\mathrm{L}^{-1}$ in the 325 and $500 \mathrm{~m}$ traps, respectively (Fig. 5b). Het-1 was detected in the 325 and $500 \mathrm{~m}$ traps but not in the $150 \mathrm{~m}$ trap. Het- 1 counts were $5.8 \times 10^{6}$ and $1.1 \times 10^{7}$ nifH copies $\mathrm{L}^{-1}$ at the 325 and $500 \mathrm{~m}$ traps, respectively (Fig. 5b).

In addition to exported Trichodesmium and RhizosoleniaRichelia associations, the small unicellular UCYN-B $(<4 \mu \mathrm{m})$ was also found in the sediment traps, including the deeper $(500 \mathrm{~m})$ traps. UCYN-B is often associated with larger phytoplankton such as the diatom Climacodium frauenfeldianum (Bench et al., 2013) or in colonial phenotypes ( $>10 \mu \mathrm{m}$ fraction) as has been observed in the northern tropical Pacific (ALOHA) (Foster et al., 2013). Sedimenting UCYN-B was detected during the VAHINE mesocosm experiment in the New Caledonian lagoon in shallow $(15 \mathrm{~m})$ sediment traps (Bonnet et al., 2016) and were also highly abundant in a floating sediment trap deployed at $75 \mathrm{~m}$ for $24 \mathrm{~h}$ in the North Pacific Subtropical Gyre (Sohm et al., 2011). Thus our data substantiate earlier conclusions that UCYN, which forms large aggregates (increasing actual size and sinking velocities), can efficiently contribute to export in oligotrophic systems (Bonnet et al., 2016). Increase in aggregate size could also occur with depth, possibly due to the high concentrations of TEP produced at the surface layer that pro- vide a nutrient source and enhance aggregation as they sink down the water column (Berman-Frank et al., 2016).

The sinking rates of aggregates in the water column depend on factors such as fluid viscosity, particle source material, morphology, density and variable particle characteristics. Sinking velocities of diatoms embedded in aggregates are generally fast (50-200 $\mathrm{m} \mathrm{d}^{-1}$ ) (Asper, 1987; Alldredge, 1998) compared with those of individually sinking cells $\left(1^{-10} \mathrm{~m} \mathrm{~d}^{-1}\right)$ (Culver and Smith, 1989), allowing aggregated particles to sink out of the photic zone to depth. Assuming a sinking rate of Trichodesmium-based aggregates of 150-200 $\mathrm{m} \mathrm{d}^{-1}$ (Bar-Zeev et al., 2013), we would need to shift the time frame by 1 day to see whether PCD measured from the surface waters is coupled with changes in organic matter reflected in the $150 \mathrm{~m}$ sediment traps. Thus, at LDA, examining metacaspase activities from the surface with mass flux and particulate matter obtained $24 \mathrm{~h}$ later yielded a significant positive correlation between these two parameters (Fig. 5c).

LDA had the highest export flux and particulate matter found in its traps relative to LDB and LDC. Diazotrophs contributed $\sim 36 \%$ to PC export in the $325 \mathrm{~m}$ trap at LDA, with Trichodesmium comprising the bulk of diazotrophs (Caffin et al., 2018). In contrast, at LDB, we found lower flux rates and lower organic material in the traps. Trichodesmium contributed the bulk of diazotroph biomass at the $150 \mathrm{~m}$ trap. We believe that at LDB the decline phase began only halfway through our sampling and thus the resulting export efficiency we obtained for the 5 days at station was relatively low compared to the total amount of surface biomass. Moreover, considering export rates, and the experimental time frame, most of the diazotrophic population may have been directly exported to the traps only after we left the station (i.e., time frame $>5$ days). This situation is different from the bloom at LDA, where enhanced mortality, biomass deterioration and bloom crash were initiated 1-2 weeks before our arrival and sampling at the station. Thus, at LDA, elevated mass flux and higher concentrations of organic matter were obtained from all three depths of the deployed traps.

In the field, especially in the surface layers of the oligotrophic oceanic regions, dead cells are rarely seen at later stages (Berges and Choi, 2014; Segovia et al., 2018). This is due to the fact that dying and dead cells are utilized quickly and recycled within the food web and upper surface layer. However, under bloom conditions, when biomass is high, the fate of the extensive biomass is more complicated (Bonnet et al., 2015). PCD-induced cell death, combined with buoyancy loss, can lead to rapid sinking to depth of the biomass at a speed that would prevent large feeding events on this biomass. We previously measured POC export in our laboratory under controlled conditions (Bar-Zeev et al., 2013). Here, using sediment traps, we measured POC fluxes as well as specific indices (nifH reads) of Trichodesmium and other diazotrophs which were measured for several days at the surface where high biomass accumulations were found. This in- 

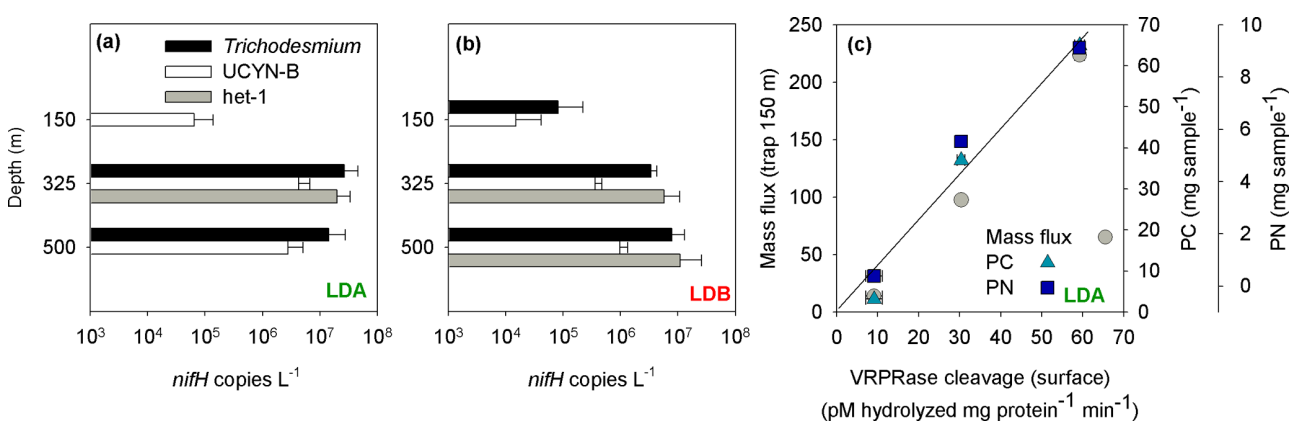

Figure 5. (a) Diazotrophic abundance (nifH copies $\mathrm{L}^{-1}$ ) of Trichodesmium (black bars), UCYN-B (white bars) and het-1 (grey bars) recovered in sediment traps at the LDA station. (b) Diazotrophic abundance (nifH copies $\mathrm{L}^{-1}$ ) of Trichodesmium (black bars), UCYN-B (white bars) and het-1 (grey bars) recovered in sediment traps at the LDB station. Abundance was measured from the accumulated material on day 5 at each station. Sediment traps were deployed at the LD station at 150, 325 and $500 \mathrm{~m}$. Error bars represent \pm 1 standard deviation $(n=3)$. (c) Relationship between metacaspase activity (pmol hydrolyzed mg protein ${ }^{-1} \mathrm{~min}^{-1}$ ) measured at the surface waters of LDA station assessed by cleavage of the canonical fluorogenic substrate, Ac-VRPR-AMC and mass flux rates $\left(\mathrm{mg} \mathrm{m}^{2} \mathrm{~h}^{-1}\right)$ (grey circle), particulate carbon $\left(\mathrm{PC}, \mathrm{mg} \mathrm{sample}^{-1}\right)$ (green triangle) and particulate nitrogen (PN, mg sample ${ }^{-1}$ ) (blue square) measured in the sediment trap deployed at $150 \mathrm{~m}$. A 1-day shift between metacaspase activities at the surface showed a significant positive correlation with mass flux and particulate matter obtained in the sediment trap at LDA station at $150 \mathrm{~m}$.

dicates that under bloom conditions when biomass is high some of the cell pellets do sink down out of the food web.

\section{Conclusion and implications}

Our specific objective in this study was to examine whether diazotroph mortality mediated by PCD can lead to higher fluxes of organic matter sinking to depth. The OUTPACE cruise provided this opportunity in two out of three long duration (5-day) stations where large surface blooms of diazotrophs principally comprised of Trichodesmium, UCYN$\mathrm{B}$ and diatom-diazotroph associations of RhizosoleniaRichelia were encountered. We demonstrate (to our knowledge for the first time) metabolically active metacaspases in oceanic populations of Richelia and Trichodesmium. Moreover, metacaspase activities were significantly correlated to caspase-like activities at both LDA and LDB stations. Both caspase and metacaspase-protein families are independent yet characteristic of PCD-induced mortality. Evidence from drifting sediment traps, deployed for 5 days at the two stations, showed high TEP concentrations formed at surface and shifting to depth, increasing numbers of diazotrophs in sediment traps (from 150, 325 and $500 \mathrm{~m}$ depths), and a timeshifted correlation between metacaspase activity (signifying PCD) and vertical fluxes of PC and PN.

However, our results also delineate the natural variability of biological oceanic populations. The two stations, LDA and LDB, were characterized by biomass at physiologically different stages. The biomass from LDA displayed more pronounced mortality that had begun prior to our arrival at station. In contrast, satellite data indicated that at LDB, the surface Trichodesmium bloom was sustained for at least a month prior to the ship's arrival and remained high for the first 3 days of our sampling before declining by $40 \%$ on day 5. As sediment trap material was examined during a short time frame, of only 5 days at each LD station, we assume that a proportion of the sinking diazotrophs and organic matter were not yet collected in the traps and either had sunk before trap deployment or would sink after we left the stations. Thus, these different historical conditions, which influence physiological status at each location, also impacted the specific results we obtained and emphasized a priori the importance of comprehensive spatial and temporal sampling that would facilitate a more holistic understanding of the dynamics and consequences of bloom formation and fate in the oceans.

Data availability. All data and metadata are available from the French INSU/CNRS LEFE CYBER database (scientific coordinator: Hervé Claustre; data manager and webmaster: Catherine Schmechtig) at the following web address: http://www.obs-vlfr. fr/proof/php/outpace/outpace.php (INSU/CNRS LEFE CYBER, 2017).

Supplement. The supplement related to this article is available online at: https://doi.org/10.5194/bg-15-3893-2018-supplement.

Author contributions. IBF, DS and SB conceived and designed the investigation linking PCD to vertical flux within the OUTPACE project. NB, MS, AC, MPP, NL, CD and RAF participated in the collection and analysis of samples. DS analyzed samples and data. DS and IBF wrote the manuscript with contributions from all coauthors. 
Competing interests. The authors declare that they have no conflict of interest.

Special issue statement. This article is part of the special issue "Interactions between planktonic organisms and biogeochemical cycles across trophic and $\mathrm{N}_{2}$ fixation gradients in the western tropical South Pacific Ocean: a multidisciplinary approach (OUTPACE experiment)". It is not associated with a conference.

Acknowledgements. This research is a contribution of the OUTPACE (Oligotrophy from UITra-oligotrophy PACific Experiment) project (https://outpace.mio.univ-amu.fr/, last access: June 2018) funded by the Agence Nationale de la Recherche (grant ANR-14CE01-0007-01), the LEFE-CyBER program (CNRS-INSU), the Institut de Recherche pour le Développement (IRD), the GOPS program (IRD) and the CNES (BC T23, ZBC 4500048836). The OUTPACE cruise (https://doi.org/10.17600/15000900) was managed by the MIO (OSU Institut Pytheas, AMU) from Marseilles (France). The authors thank the crew of the R/V L'Atalante for outstanding shipboard operations. Gilles Rougier and Marc Picheral are warmly thanked for their efficient help in CTD rosette management and data processing, as is Catherine Schmechtig for the LEFE-CyBER database management. Aurelia Lozingot is acknowledged for the administrative work. All data and metadata are available at the following web address: http://www.obs-vlfr.fr/proof/php/outpace/outpace.php (last access: June 2018). We thank Olivier Grosso (MIO) and Sandra Hélias (MIO) for the phosphate data and François Catlotti (MIO) for the zooplankton data. The ocean color satellite products were provided by CLS in the framework of the CNES-OUTPACE project (PI Andrea Michelangelo Doglioli) and the video is courtesy of Alain de Verneil. Rachel A. Foster acknowledges Stina Höglund and the Image Facility of Stockholm University and the Wenner-Gren Institute for access and assistance in confocal microscopy. The participation of Natalia Belkin, Dina Spungin and Ilana Berman-Frank in the OUTPACE experiment was supported through a collaborative grant to Ilana Berman-Frank and Sophie Bonnet from Israel Ministry of Science and Technology Israel and the High Council for Science and Technology (HCST) France grant 2012/3-9246 and United States-Israel Binational Science Foundation (BSF) grant no. 2008048 to Ilana Berman-Frank. Rachel A. Foster was funded by the Knut and Alice Wallenberg Stiftelse and acknowledges the helpful assistance of Lotta Berntzon. This work is in partial fulfillment of the requirements for a $\mathrm{PhD}$ thesis for Dina Spungin at Bar-Ilan University.

Edited by: Thierry Moutin

Reviewed by: two anonymous referees

\section{References}

Alldredge, A.: The carbon, nitrogen and mass content of marine snow as a function of aggregate size, Deep-Sea Res. Pt. I, 45, 529-541, 1998.

Aminot, A. and Kérouel, R.: Dosage automatique des nutriments dans les eaux marines: méthodes en flux continu, Ed. Ifremer,
Plouzanne, France, Méthodes d'analyse en milieu marin, Ifremer, 188 pp., 2007.

Asper, V. L.: Measuring the flux and sinking speed of marine snow aggregates, Deep-Sea Res. Pt. A, 34, 1-17, 1987.

Asplund-Samuelsson, J.: The art of destruction: revealing the proteolytic capacity of bacterial caspase homologs, Mol. Microbiol., 98, 1-6, 2015.

Asplund-Samuelsson, J., Bergman, B., and Larsson, J.: Prokaryotic caspase homologs: phylogenetic patterns and functional characteristics reveal considerable diversity, PLoS One, 7, e49888, https://doi.org/10.1371/journal.pone.0049888, 2012.

Barboza Tenório, M. M., Dupouy, C., Rodier, M., and Neveux, J.: Trichodesmium and other planktonic cyanobacteria in New Caledonian waters (SW tropical Pacific) during an El Niño episode, Aquat. Microb. Ecol., 81, 219-241, https://doi.org/10.3354/ame01873, 2018.

Bar-Zeev, E., Berman-Frank, I., Liberman, B., Rahav, E., Passow, U., and Berman, T.: Transparent exopolymer particles: Potential agents for organic fouling and biofilm formation in desalination and water treatment plants, Desalin. Water Treat., 3, 136-142, 2009.

Bar-Zeev, E., Avishay, I., Bidle, K. D., and Berman-Frank, I.: Programmed cell death in the marine cyanobacterium Trichodesmium mediates carbon and nitrogen export, ISME J., 7, 2340-2348, 2013.

Bench, S. R., Heller, P., Frank, I., Arciniega, M., Shilova, I. N., and Zehr, J. P.: Whole genome comparison of six Crocosphaera watsonii strains with differing phenotypes, J. Phycol., 49, 786801, 2013.

Berges, J. A. and Choi, C. J.: Cell death in algae: physiological processes and relationships with stress, Perspectives in Phycology, 1, 103-112, 2014.

Bergman, B., Sandh, G., Lin, S., Larsson, J., and Carpenter, E. J.: Trichodesmium - a widespread marine cyanobacterium with unusual nitrogen fixation properties, FEMS Microbiol. Rev., 37, 117, 2012.

Berman-Frank, I. and Dubinsky, Z.: Balanced growth in aquatic plants: Myth or reality? Phytoplankton use the imbalance between carbon assimilation and biomass production to their strategic advantage, BioScience, 49, 29-37, 1999.

Berman-Frank, I., Bidle, K., Haramaty, L., and Falkowski, P.: The demise of the marine cyanobacterium, Trichodesmium spp., via an autocatalyzed cell death pathway, Limnol. Oceanogr., 49, 997-1005, 2004.

Berman-Frank, I., Rosenberg, G., Levitan, O., Haramaty, L., and Mari, X.: Coupling between autocatalytic cell death and transparent exopolymeric particle production in the marine cyanobacterium Trichodesmium, Environ. Microbiol., 9, 1415-1422, https://doi.org/10.1111/j.1462-2920.2007.01257.x, 2007.

Berman-Frank, I., Spungin, D., Rahav, E., Van Wambeke, F., TurkKubo, K., and Moutin, T.: Dynamics of transparent exopolymer particles (TEP) during the VAHINE mesocosm experiment in the New Caledonian lagoon, Biogeosciences, 13, 3793-3805, https://doi.org/10.5194/bg-13-3793-2016, 2016.

Bidle, K. D.: The molecular ecophysiology of programmed cell death in marine phytoplankton, Annu. Rev. Mar. Sci., 7, 341375, 2015.

Bidle, K. D. and Bender, S. J.: Iron starvation and culture age activate metacaspases and programmed cell death in the marine 
diatom Thalassiosira pseudonana, Eukaryotic Cell, 7, 223-236, https://doi.org/10.1128/ec.00296-07, 2008.

Bonnet, S., Guieu, U., Chiaverini, J., Ras, J., and Stock, A.: Effect of atmospheric nutrients on the autotrophic communities in a low nutrient, low chlorophyll system, Limnol. Oceanogr., 50, 18101819, 2005.

Bonnet, S., Berthelot, H., Turk-Kubo, K., Fawcett, S., Rahav, E., L'Helguen, S., and Berman-Frank, I.: Dynamics of $\mathrm{N}_{2}$ fixation and fate of diazotroph-derived nitrogen in a low-nutrient, low-chlorophyll ecosystem: results from the VAHINE mesocosm experiment (New Caledonia), Biogeosciences, 13, 2653-2673, https://doi.org/10.5194/bg-13-2653-2016, 2016.

Bonnet, S., Caffin, M., Berthelot, H., and Moutin, T.: Hot spot of $\mathrm{N}_{2}$ fixation in the western tropical South Pacific pleads for a spatial decoupling between $\mathrm{N}_{2}$ fixation and denitrification, P. Natl. Acad. Sci. USA, 114, E2800-E2801, https://doi.org/10.1073/pnas.1619514114, 2017.

Bonnet, S., Caffin, M., Berthelot, H., Grosso, O., Benavides, M., Helias-Nunige, S., Guieu, C., Stenegren, M., and Foster, R. A.: In depth characterization of diazotroph activity across the Western Tropical South Pacific hot spot of $\mathrm{N}_{2}$ fixation, Biogeosciences Discuss., https://doi.org/10.5194/bg-2017-567, in review, 2018.

Brown, J. M., LaBarre, B. A., and Hewson, I.: Characterization of Trichodesmium-associated viral communities in the eastern Gulf of Mexico, FEMS Microbiol. Ecol., 84, 603-613, 2013.

Brussaard, C. P. D., Mari, X., Van Bleijswijk, J. D. L., and Veldhuis, M. J. W.: A mesocosm study of Phaeocystis globosa (Prymnesiophyceae) population dynamics - II. Significance for the microbial community, Harmful Algae, 4, 875-893, 2005.

Caffin, M., Moutin, T., Foster, R. A., Bouruet-Aubertot, P., Doglioli, A. M., Berthelot, H., Guieu, C., Grosso, O., Helias-Nunige, S., Leblond, N., Gimenez, A., Petrenko, A. A., de Verneil, A., and Bonnet, $\mathrm{S}$.: $\mathrm{N}_{2}$ fixation as a dominant new $\mathrm{N}$ source in the western tropical South Pacific Ocean (OUTPACE cruise), Biogeosciences, 15, 2565-2585, https://doi.org/10.5194/bg-152565-2018, 2018.

Capone, D. G., Zehr, J. P., Paerl, H. W., Bergman, B., and Carpenter, E. J.: Trichodesmium, a globally significant marine cyanobacterium, Science, 276, 1221-1229, 1997.

Carpenter, E. J., Subramaniam, A., and Capone, D. G.: Biomass and primary productivity of the cyanobacterium Trichodesmium spp. in the tropical N Atlantic ocean, Deep-Sea Res. Pt. I, 51, 173203, https://doi.org/10.1016/j.dsr.2003.10.006, 2004.

Cauwet, G.: HTCO method for dissolved organic carbon analysis in seawater: influence of catalyst on blank estimation, Mar. Chem., 47, 55-64, 1994.

Church, M. J., Jenkins, B. D., Karl, D. M., and Zehr, J. P.: Vertical distributions of nitrogen-fixing phylotypes at Stn ALOHA in the oligotrophic North Pacific Ocean, Aquat. Microb. Ecol., 38, 314, 2005.

Culver, M. E. and Smith, W. O.: Effects of environmental variation on sinking rates of marine phytoplankton, J. Phycol., 25, 262270,1989

de Verneil, A., Rousselet, L., Doglioli, A. M., Petrenko, A. A., and Moutin, T.: The fate of a southwest Pacific bloom: gauging the impact of submesoscale vs. mesoscale circulation on biological gradients in the subtropics, Biogeosciences, 14, 3471-3486, https://doi.org/10.5194/bg-14-3471-2017, 2017.
Dupouy, C., Neveux, J., Subramaniam, A., Mulholland, M. R., Montoya, J. P., Campbell, L., Capone, D. G., and Carpenter, E. J.: Satellite captures Trichodesmium blooms in the Southwestern Tropical Pacific, EOS T. Am. Geophys. Un., 81, 13-16, 2000.

Dupouy, C., Benielli-Gary, D., Neveux, J., Dandonneau, Y., and Westberry, T. K.: An algorithm for detecting Trichodesmium surface blooms in the South Western Tropical Pacific, Biogeosciences, 8, 3631-3647, https://doi.org/10.5194/bg-8-36312011, 2011.

Engel, A.: Distribution of transparent exopolymer particles (TEP) in the northeast Atlantic Ocean and their potential significance for aggregation processes, Deep-Sea Res. Pt. I, 51, 83-92, 2004.

Engel, A., Goldthwait, S., Passow, U., and Alldredge, A.: Temporal decoupling of carbon and nitrogen dynamics in a mesocosm diatom bloom, Limnol. Oceanogr., 47, 753-761, 2002.

Foster, R. A., Subramaniam, A., Mahaffey, C., Carpenter, E. J., Capone, D. G., and Zehr, J. P.: Influence of the Amazon River plume on distributions of free-living and symbiotic cyanobacteria in the western tropical north Atlantic Ocean, Limnol. Oceanogr., 52, 517-532, 2007.

Foster, R. A., Sztejrenszus, S., and Kuypers, M. M.: Measuring carbon and $\mathrm{N}_{2}$ fixation in field populations of colonial and free-living unicellular cyanobacteria using nanometer-scale secondary ion mass spectrometry, J. Phycol., 49, 502-516, 2013.

Fukao, T., Kimoto, K., and Kotani, Y.: Production of transparent exopolymer particles by four diatom species, Fisheries Sci., 76, 755-760, 2010.

Garcia, N., Raimbault, P., and Sandroni, V.: Seasonal nitrogen fixation and primary production in the Southwest Pacific: nanoplankton diazotrophy and transfer of nitrogen to picoplankton organisms, Mar. Ecol.-Prog. Ser., 343, 25-33, 2007.

Hewson, I., Govil, S. R., Capone, D. G., Carpenter, E. J., and Fuhrman, J. A.: Evidence of Trichodesmium viral lysis and potential significance for biogeochemical cycling in the oligotrophic ocean, Aquat. Microb. Ecol., 36, 1-8, 2004.

INSU/CNRS LEFE CYBER: available at: http://www.obs-vlfr. fr/proof/php/outpace/outpace.php (last access: 14 June 2018), 2017.

Jiang, X. D., Lonsdale, D. J., and Gobler, C. J.: Grazers and vitamins shape chain formation in a bloom-forming dinoflagellate, Cochlodinium polykrikoides, Oecologia, 164, 455-464, https://doi.org/10.1007/s00442-010-1695-0, 2010.

Kerbrat, A. S., Amzil, Z., Pawlowiez, R., Golubic, S., Sibat, M., Darius, H. T., Chinain, M., and Laurent, D.: First evidence of palytoxin and 42-hydroxy-palytoxin in the marine cyanobacterium Trichodesmium, Mar. Drugs, 9, 543-560, 2011.

Le Bouteiller, A., Blanchot, J., and Rodier, M.: Size distribution patterns of phytoplankton in the western Pacific: towards a generalization for the tropical open ocean, Deep-Sea Res. Pt. A, 39, 805-823, 1992.

Minina, E., Coll, N., Tuominen, H., and Bozhkov, P.: Metacaspases versus caspases in development and cell fate regulation, Cell Death Differ., 24, 1314-1325, 2017.

Moisander, P. H., Beinart, R. A., Voss, M., and Zehr, J. P.: Diversity and abundance of diazotrophic microorganisms in the South China Sea during intermonsoon, ISME J., 2, 954-967, https://doi.org/10.1038/ismej.2008.51, 2008.

Moisander, P. H., Beinart, R. A., Hewson, I., White, A. E., Johnson, K. S., Carlson, C. A., Montoya, J. P., and Zehr, 
J. P.: Unicellular Cyanobacterial Distributions Broaden the Oceanic $\mathrm{N}_{2}$ Fixation Domain, Science, 327, 1512-1514, https://doi.org/10.1126/science.1185468, 2010.

Moutin, T., Doglioli, A. M., de Verneil, A., and Bonnet, S.: Preface: The Oligotrophy to the UlTra-oligotrophy PACific Experiment (OUTPACE cruise, 18 February to 3 April 2015), Biogeosciences, 14, 3207-3220, https://doi.org/10.5194/bg-143207-2017, 2017.

O'Neil, J. M.: The colonial cyanobacterium Trichodesmium as a physical and nutritional substrate for the harpacticoid copepod Macrosetella gracilis, J. Plankton Res., 20, 43-59, 1998.

O'Neil, J. M. and Roman, M. R.: Ingestion of the Cyanobacterium Trichodesmium spp. by Pelagic Harpacticoid Copepods Macrosetella, Miracia and Oculostella, Hydrobiologia, 293, 235-240, 1994.

Ohki, K.: A possible role of temperate phage in the regulation of Trichodesmium biomass, Bulletin de l'institute oceanographique, Monaco, 19, 287-291, 1999.

Passow, U.: Transparent exopolymer particles (TEP) in aquatic environments, Prog. Oceanogr., 55, 287-333, 2002.

Passow, U. and Alldredge, A. L.: A dye binding assay for the spectrophotometeric measurement of transparent exopolymer particles (TEP), Limnol. Oceanogr., 40, 1326-1335, 1995.

Rodier, M. and Le Borgne, R.: Population dynamics and environmental conditions affecting Trichodesmium spp. (filamentous cyanobacteria) blooms in the south-west lagoon of New Caledonia, J. Exp. Mar. Biol. Ecol., 358, 20-32, https://doi.org/10.1016/j.jembe.2008.01.016, 2008.

Rodier, M. and Le Borgne, R.: Population and trophic dynamics of Trichodesmium thiebautii in the SE lagoon of New Caledonia. Comparison with T. erythraeum in the SW lagoon, Mar. Pollut. Bull., 61, 349-359, https://doi.org/10.1016/j.marpolbul.2010.06.018, 2010.

Segovia, M., Lorenzo, M. R., Iñiguez, C., and García-Gómez C.: Physiological stress response associated with elevated $\mathrm{CO}_{2}$ and dissolved iron in a phytoplankton community dominated by the coccolithophore Emiliania huxleyi, Mar. Ecol.-Prog. Ser., 586, 73-89, 2018.

Short, S. M., Jenkins, B. D., and Zehr, J. P.: Spatial and temporal distribution of two diazotrophic bacteria in the Chesapeake Bay, Appl. Environ. Microbiol., 70, 2186-2192, 2004.

Sohm, J. A., Edwards, B. R., Wilson, B. G., and Webb, E. A.: Constitutive extracellular polysaccharide (EPS) production by specific isolates of Crocosphaera watsonii, Front. Microbiol., 2, 229, 2011

Spungin, D., Pfreundt, U., Berthelot, H., Bonnet, S., AlRoumi, D., Natale, F., Hess, W. R., Bidle, K. D., and Berman-Frank, I.: Mechanisms of Trichodesmium demise within the New Caledonian lagoon during the VAHINE mesocosm experiment, Biogeosciences, 13, 4187-4203, https://doi.org/10.5194/bg-13-41872016, 2016.
Stenegren, M., Caputo, A., Berg, C., Bonnet, S., and Foster, R. A.: Distribution and drivers of symbiotic and free-living diazotrophic cyanobacteria in the western tropical South Pacific, Biogeosciences, 15, 1559-1578, https://doi.org/10.5194/bg-151559-2018, 2018.

Sugimura, Y. and Suzuki, Y.: A high-temperature catalytic oxidation method for the determination of non-volatile dissolved organic carbon in seawater by direct injection of a liquid sample, Mar. Chem., 24, 105-131, 1988.

Thamatrakoln, K., Korenovska, O., Niheu, A. K., and Bidle, K. D.: Whole-genome expression analysis reveals a role for deathrelated genes in stress acclimation of the diatom Thalassiosira pseudonana, Environ. Microbiol., 14, 67-81, 2012.

Thompson, A. W., Foster, R. A., Krupke, A., Carter, B. J., Musat, N., Vaulot, D., Kuypers, M. M., and Zehr, J. P.: Unicellular cyanobacterium symbiotic with a single-celled eukaryotic alga, Science, 337, 1546-1550, 2012.

Tsiatsiani, L., Van Breusegem, F., Gallois, P., Zavialov, A., Lam, E., and Bozhkov, P.: Metacaspases, Cell Death Differ., 18, 12791288, 2011.

Turk-Kubo, K. A., Frank, I. E., Hogan, M. E., Desnues, A., Bonnet, S., and Zehr, J. P.: Diazotroph community succession during the VAHINE mesocosm experiment (New Caledonia lagoon), Biogeosciences, 12, 7435-7452, https://doi.org/10.5194/bg-127435-2015, 2015.

Urbani, R., Magaletti, E., Sist, P., and Cicero, A. M.: Extracellular carbohydrates released by the marine diatoms Cylindrotheca closterium, Thalassiosira pseudonana and Skeletonema costatum: Effect of P-depletion and growth status, Sci. Total Environ., 353, 300-306, 2005.

Vardi, A., Haramaty, L., Van Mooy, B. A., Fredricks, H. F., Kimmance, S. A., Larsen, A., and Bidle, K. D.: Host-virus dynamics and subcellular controls of cell fate in a natural coccolithophore population, P. Natl. Acad. Sci. USA, 109, 19327-19332, 2012.

Verdugo, P. and Santschi, P. H.: Polymer dynamics of DOC networks and gel formation in seawater, Deep-Sea Res. Pt. II, 57, 1486-1493, 2010.

Westberry, T. K. and Siegel, D. A.: Spatial and temporal distribution of Trichodesmium blooms in the world's oceans, Global Biogeochem. Cy., 20, GB4016, https://doi.org/10.1029/2005GB002673, 2006. 